\title{
Weaknesses in Motivation and in Establishing a Meritocratic System: A Portrait of the Portuguese Public Administration
}

\author{
Adriana Z. F. C. Nishimura ${ }^{1, *(\mathbb{D})}$, Ana Moreira ${ }^{2}$, Maria José Sousa ${ }^{3} \mathbb{D}$ and Manuel Au-Yong-Oliveira ${ }^{1,4} \mathbb{D}^{\mathbb{D}}$ \\ 1 GOVCOPP (UA), Department of Economics, Management, Industrial Engineering and Tourism (DEGEIT), \\ University of Aveiro, 3810-193 Aveiro, Portugal; mao@ua.pt \\ 2 Department of Social and Organizational Psychology, University Institute of Psychological, Social and Life \\ Sciences (ISPA-IU), 1149-041 Lisbon, Portugal; amoreira@ispa.pt \\ 3 Business Research Unit (BRU-Iscte), University Institute of Lisbon (ISCTE-IUL), 1649-026 Lisbon, Portugal; \\ maria.jose.sousa@iscte-iul.pt \\ 4 INESC TEC, Campus da FEUP, University of Porto, 4200-465 Porto, Portugal \\ * Correspondence: adriana.nishimura@ua.pt
}

Citation: Nishimura, Adriana Z. F. C., Ana Moreira, Maria José Sousa, and Manuel Au-Yong-Oliveira. 2021. Weaknesses in Motivation and in Establishing a Meritocratic System: A Portrait of the Portuguese Public Administration. Administrative Sciences 11: 87. https://doi.org/ 10.3390/admsci11030087

Received: 2 July 2021

Accepted: 19 August 2021

Published: 24 August 2021

Publisher's Note: MDPI stays neutral with regard to jurisdictional claims in published maps and institutional affiliations.

Copyright: (c) 2021 by the authors. Licensee MDPI, Basel, Switzerland. This article is an open access article distributed under the terms and conditions of the Creative Commons Attribution (CC BY) license (https:// creativecommons.org/licenses/by/ $4.0 /)$.

\begin{abstract}
The complexities of Public Administration have gained the growing attention of scholars around the world, mainly due to the impacts of the reforms implemented under the doctrine of New Public Management (which aims to apply concepts and practices of private management in public management) on civil servants. The aim of this study is to find out how Portuguese citizens evaluate the Portuguese Public Administration under the aspects of bureaucracy, organisation of human resources, innovation, skills and attitudes of civil servants, its motivation and recognition; and to verify if there are differences of opinion between respondents working in public sector and respondents from other sectors. This study follows a quali-quantitative approach, and data were collected through an online survey in the period from June to December 2020. The survey was answered by 1119 citizens from all districts of Portugal. The main findings reveal a still high level of bureaucracy in the Portuguese Public Administration; weaknesses in the management of human resources, namely regarding the motivation and recognition of civil servants; and difficulties in the establishment of a meritocratic system of recruitment and performance evaluation of civil servants. Statistically significant evaluation differences (chi-square test and non-parametric Mann-Whitney U tests, involving five hypotheses) were found between the public sector and other sectors, except for the motivation variable.
\end{abstract}

Keywords: public administration; Portuguese public administration; Portugal; bureaucracy; motivation; civil servants; meritocracy; new public management

\section{Introduction}

Public Administration (PA) presents an increasing complexity throughout its evolution as a science worldwide. Governance models have been transforming through history, especially in the contemporary era, as a response to profound social, economic, cultural and political changes in countries (Wright 1997; Lane 1995). The advent of economic globalisation generated the need for PA modernisation, guided by an essentially bureaucratic model until the 1980s. Principles of New Public Management (NPM), a new management model based on paradigms and practices of private management, were widely disseminated in the Western democracies (Gruening 2001; Hood 1994), leading states to implement reforms in their public administrations at the central and local levels.

Portugal is no exception to the rule (Santinha et al. 2021; Corte-Real 2008; Madureira and Ferraz 2010) and, particularly after joining the European Union (EU), in 1986, has experienced, over the course of successive constitutional governments, the implementation of reform measures based on NPM, aimed at streamlining the state's administrative apparatus, reducing public expenditure and removing bureaucracy from processes, gains in 
efficiency and effectiveness in the provision of public services, among other objectives of a more operational nature (Madureira and Ferraz 2010; Rocha and Araújo 2006).

The rationalisation, modernisation and empowerment of the PA is one of the strategic objectives of the Portugal 2020 Partnership Agreement, in line with the Europe 2020 Strategy and the National Reform Programme, established by the XXI Constitutional Government (the Portuguese Republic 2018). The Support System for the Modernisation and Capacitation of the Public Administration (SAMA 2020), managed by the Agency for Administrative Modernisation (AMA), has received a financial allocation of EUR 362 million in EU funds to support qualification and motivation actions for civil servants (AMA 2021), and since its implementation in 2014, more than 300 qualification and motivation projects for civil servants have been funded with Portugal 2020 resources. Despite these investments, the Economic and Social Council of Portugal (CES) has warned about the need for an enhancement of human resources in the PA in all its dimensions: careers, professional training, working conditions and salaries (CES 2019).

It is noteworthy that the EU Recovery and Resilience Plan (known as "bazooka") provides a budget allocation of EUR 578 million for capacity building, digitalisation, interoperability and cybersecurity actions of the Portuguese PA (Expresso 2021), in line with the axis Exploiting technology of the Strategy for Innovation and Modernisation of the State and Public Administration 2020-2023, approved by the Resolution of the Council of Ministers No. 55/2020, of 31 July 2020 (Diário da República Eletrónico 2021). Table 1 summarises the Strategy.

Table 1. Strategy for Innovation and Modernisation of the State and Public Administration 2020-2023.

\begin{tabular}{|c|c|c|}
\hline \multirow{5}{*}{$\begin{array}{l}\text { Strategy for Innovation } \\
\text { and Modernisation of the } \\
\text { State and Public } \\
\text { Administration 2020-2023 }\end{array}$} & Axes & Strategic objectives \\
\hline & 1. Investing in people & $\begin{array}{l}\text { 1.1 develop and renew leadership } \\
1.2 \text { mobilising and empowering workers } \\
1.3 \text { involving workers in cultural change }\end{array}$ \\
\hline & 2. Developing management & $\begin{array}{ll}2 & \\
2.1 & \text { strengthen performance management to improve the quality } \\
& \text { of public services } \\
2.2 & \text { planning human resources in an integrated way } \\
2.3 & \text { investing in administrative simplification } \\
2.4 & \text { promoting innovation in public management }\end{array}$ \\
\hline & 3. Exploring technology & $\begin{array}{l}\text { strengthening global governance of technology } \\
\text { improving interoperability and integration of services } \\
\text { managing the data ecosystem with security and transparency }\end{array}$ \\
\hline & 4. Strengthening proximity & $\begin{array}{l}\text { promote integration and inclusion in public care } \\
\text { encouraging citizens' participation } \\
\text { deepening the decentralisation of powers to local authorities } \\
\text { strengthen local public services through deconcentration to } \\
\text { the regional level }\end{array}$ \\
\hline
\end{tabular}

Source: Own elaboration (data from the Resolution of the Council of Ministers $N^{\circ}$ 55/2020).

As we have seen, in addition to the idiosyncrasies of a management model that is particularly normative, the Portuguese PA still faces added difficulties in the management of its human resources, such as the recurring reforms that froze salaries and benefits, shortcomings in the organisation of personnel, the use of a performance assessment system (SIADAP) that is criticised by scholars and civil servants for not being fair and meritocratic, the lack of prestige and recognition of employees by society, and low opportunities of functional progression (Rosa 2020; Madureira and Rodrigues 2015; Rato 2015; Pedro 2015; Fraga 2014; Lopes 2012).

All the complexity involved in the PA has demanded a broad approach to studies that allow for a better understanding of its particularities and challenges over time. In 
this context, it is particularly important to know the opinion of citizens about the PA and the management of its human resources since citizens are important stakeholders in the PA, presenting themselves as "customers" of its services (Mintzberg 1996).

This study presents a theoretical-empirical approach and aims to know how Portuguese citizens evaluate the Portuguese PA in the following aspects:

(1) The level of the bureaucracy of the PA bodies;

(2) Organisation and distribution of human resources;

(3) Efficiency and quality of public services;

(4) Skills and attitudes of civil servants;

(5) Recognition of civil servants;

(6) Innovation in the PA.

The structure of this article is divided into six sections: the introduction (the current section); a brief literature review, focused on PA models and the NPM, motivation in public service and innovation; the methods used in the research; the presentation and discussion of results; and the conclusions, where the limitations of the study and perspectives for future research are also presented.

\section{Literature Review}

\subsection{Portuguese Public Administration, Reform and New Public Management}

To contextualise contemporary PA, it is necessary to recall the administration models that made it evolve over time. According to Violin (2007, p. 225), before the PA evolved into a bureaucratic model, the state apparatus was patrimonialist, "in which public and private property were confused, and there was nepotism, patronage and corruption". The beginnings of a patrimonialist bureaucracy in Portugal arose from a merchant bourgeoisie (Buarque de Holanda 1987).

According to Chiavenato (2009), in the patrimonialist model reigned a corrupt administration, in which public positions were donated to people chosen by the court, having as a characteristic a high remuneration in exchange for little work. Trigo (2009, p. 194) states that the stigma was created of privileged civil servants in contemporary society who "receive much and work little". In order to combat nepotism and corruption in force, the bureaucratic model of PA arose (Chiavenato 2009), which was introduced in Europe in the late 19th century (Violin 2007). The precepts of the bureaucratic model are attributed to the philosopher Max Weber (Weber 2000), for whom the purest type of rational-legal domination of the state is exercised by the bureaucratic administrative apparatus, consisting of rigid and hierarchical controls that guarantee the sovereign power of the State (Chiavenato 2009). According to Ferraz (2020), Weber's contribution essentially focused on the status of bureaucracy as an organised means for legal, economic and technical rationality.

Jamil (1998) states that an essential PA characteristic is its relationship with politics and its positioning in a broader political system. These elements configure mechanisms to control how politics directs the administration, the internal functioning of the administration and its relationship with society and citizens. According to the author, a normative concept of the relationship between politics and administration that emerged in Europe from the 17th century onwards suggests a hierarchical structure between ends and means. In this system, the bureaucracy is expected to be loyal to all governments and regimes that assume power without losing its impersonal character. In Europe, the Weberian system, based on a system of vertical hierarchies, permanent careers, impersonal treatment and promotions on the basis of merit, served this purpose (Jamil 1998).

Due to globalisation and the pressures of a new world order, the need arose for a new model of PA - the NPM, based on administrative decentralisation, flexibility, autonomy and the flattening of hierarchies, principles that were already advocated in the context of the private sector becoming more business-like (Wright 1997). Consequently, the administrative reforms emerged as a package of measures aimed at the modernisation and 
debureaucratisation of the state, replacing the "administrative state" with the "managerial state" (Lane 1995).

The term New Public Management was first used by Hood (1991) with the article "A Public Management for All Seasons?", in which he debates the assumption that NPM offers a multipurpose key to better public service delivery. Hood (1991, p. 4, and following) firstly has referenced seven components of change in the NPM doctrines:

(1) Hands-on professional management;

(2) Explicit standards and measures of performance;

(3) Greater emphasis on output controls;

(4) Shift to disaggregation of units;

(5) Shift to greater competition;

(6) Stress on private-sector styles of management practice;

(7) Stress on greater discipline and parsimony in resource use.

According to the author, not all of these seven components are equally present in the reform policies adopted by the OECD countries over the 1980s.

Rodríguez Rodríguez Bolívar et al. (2015) address that the public sector reforms undertaken by governments around the world under NPM have been achieved in different ways, and these differences are apparently caused mainly by the different administrative cultures existing among Western-style democracies (Table 2).

Table 2. Characteristics of Public Administration in Western-style states.

\begin{tabular}{|c|c|c|c|}
\hline & Anglo-Saxon Countries & $\begin{array}{c}\text { Countries in Scandinavia and } \\
\text { The Netherlands }\end{array}$ & Continental Europe Countries \\
\hline 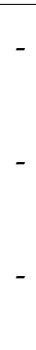 & $\begin{array}{l}\text { emphasise accountability, } \\
\text { efficiency, effectiveness and } \\
\text { value for money } \\
\text { more likely to introduce market } \\
\text { mechanisms and notions of } \\
\text { competitiveness } \\
\text { envisage the citizen primarily as } \\
\text { a client }\end{array}$ & $\begin{array}{l}\text { - } \\
\text { and Considered a mixture of Anglo-Saxon } \\
\text { - } \quad \text { reforms concerned with citizens' needs, } \\
\text { who are encouraged to participate in } \\
\text { public policy evaluation and in } \\
\text { management } \\
\text { more pragmatic version of managerial } \\
\text { reforms }\end{array}$ & 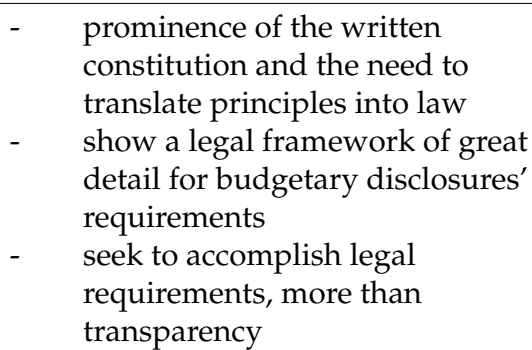 \\
\hline
\end{tabular}

Source: Own elaboration (Rodríguez Bolívar et al. 2015).

According to Hood (1991), NPM has most often been criticised in terms of an alleged contradiction between the values of "equity" and "efficiency", but any criticism of NPM doctrines needs to be grounded in terms of possible conflicts between administrative values, which varies according to factors such as whether or not it is an Anglo-Saxon country (as seen above with Rodríguez Bolívar et al. 2015), party politics, government size and macroeconomic performance. For instance, concerning the political factor, Portugal is reported by Hood (1994) as a Centre country and has adopted a medium NPM emphasis on reform policies.

Bilhim et al. (2015) address that reform models cannot be applied uncritically in countries with such distinct administrative paradigms (legal-normative model $\mathrm{X}$ managerial model). They exemplify this with the fact that civil servants, after thirty years of rhetoric about reforms in Portugal, prefer the values of equity (the normative aspect of the State) to those of efficiency (prevailing in the private administration).

Magone (2011) refers to "Neo-patrimonialism" applied to the case of the Portuguese $\mathrm{PA}$, meaning that, despite the growing importance of a democratic culture of accountability and transparency over time, sustained through continuous pressures from the OECD and the Europeanisation processes, old patterns of behaviour remain as obstacles in the reform processes.

Carvalho (2008, p. 259) states that there is an ambiguity between the models applied in administrative reform and the empirical reality, making administrative science close to a 
kind of fiction, whose theories do not clarify what exists, but only indicate what should exist, and "administrative reform is often a victim of this fiction".

As we have seen above, NPM has been debated and criticised by PA scholars around the world in several domains. Gruening (2001, p. 21), in a study on the theoretical basis of New Public Management, states that there will be new waves of reform that will remodel NPM-oriented structures, and the question of whether NPM is adequate or effective is less relevant. According to the author, "it makes no sense to argue NPM by saying: 'Look, it is made of different parts that are based on incommensurable theories. Therefore, we should reject it".

The "prescription" with the precepts of New Public Management, with the exaltation of management models originating from the business sector, is also criticised by Ongaro (2015, p. 71), for whom "a set of $x$ or y prescriptions on how to organise the public sector cannot be applied regardless of context: $x$ or $y$ will work or not work-and have different effects".

Just to name a few additional studies on the impacts of NPM applied in Portugal, Madureira et al. (2021) discuss the negative impacts of the reforms from the point of view of SIADAP, a performance evaluation system considered unfair by the majority (75\%) of public servants surveyed. On the other hand, Melo et al. (2020) find positive results in an administrative model guided by the Post-NPM (also known as the Neo-Weberian model) in the innovation processes in a teaching hospital in Portugal. Cardoso et al. (2019) analyse the NPM impacts on higher education in Portugal from the perspective of teaching staff and find a contradiction. The results point to a deterioration of working conditions, but academics maintain a positive view regarding the academic profession. Santinha et al. (2021) state that the adaptation of the private sector management style to public administration has had a crucial impact in the field of human resources, the most representative being the loss of historically attractive characteristics in the public sector, such as the guarantee of job security and predictability in promotions.

\section{Reform Measures and Overview of Civil Servant Employment in Portugal}

In Portugal, the structural changes in PA were concentrated in the post-revolutionary period, with the return to democratic rules in 1974 and entry into the European Community in 1986 (Corte-Real 2008; OECD 1995). At that time, the critical points that worked in the administrative reform were the improvement of the public service image and the recovery of its prestige, qualification of civil servants, behavioural change of leaderships, approximation of the administration to citizens (highlighting transparency), simplification of rules and decentralisation of authority (Madureira 2015; OECD 1995).

In the early 1990s, the main measures of reform adopted with the Administrative Procedure Code (Law $n^{\circ} 442 / 91$ ) were the establishment of a legal instrument empowering citizens to request public services provided in an efficient and fair way and the creation of the Lojas do Cidadão (Citizen's Shops), which allowed access to several public services in one physical location (Madureira and Ferraz 2010).

In the 2000s, performance evaluation with more objective criteria and new statutory rules for civil servants were among the main novelties in public management. Among the instruments of reform, the Restructuring Programme for the State's Central Administration (PRACE) stands out. Some of the measures taken were reduction from 518 to 187 administrative structures (64\%), reduction of $25 \%$ of the number of managerial positions, promotion of the mobility of civil servants between public organisms, implementation of an integrated system of performance assessment (SIADAP), convergence of some civil servants' rights with those of private sector employees and transformation of 1725 careers into three general careers (Madureira and Ferraz 2010; Rocha and Araújo 2006; Araújo 2005).

At this time, Portugal was already undergoing a fiscal adjustment policy to reduce its public deficit, with the Stability and Growth Programme being established in 2005. However, the severe international financial crisis of 2008 contributed to Portugal's deficit reduction targets not being met, leading to the signing of the Memorandum of Under- 
standing between the Portuguese government and the troika in 2011. Through the Central Administration Reduction and Improvement Plan (PREMAC), a variety of measures was implemented to promote an immediate cut in public spending costs, among which were limitations on staff hiring (decrease of $1-2 \%$ per year), freezing of salaries and limitation of promotions, reduction of the state's contribution to the healthcare system for civil servants, reduction of managerial positions and central administration services by at least $15 \%$, and closure of some foundations (Madureira 2015; Madureira et al. 2013).

According to the data collected in the Directorate General for Administration and Public Employment (DGAEP 2021) on 31 March 2021, Portugal had 725,777 civil servants in the public administrations, of which 13,513 occupied upper or middle management positions (INE 2021). In total, $75.7 \%$ of the civil servants were employed in central government entities, $17.3 \%$ in local government, $5.5 \%$ in regional government $(2.8 \%$ in the Regional Government of Madeira and 2.7\% in the Regional Government of Azores) and 1.5\% in social security funds. Employment in the general government sector represented $7.1 \%$ of the total population of Portugal (administration ratio), $14.4 \%$ of the labour force and $15.5 \%$ of the employed population.

Figure 1 represents the variation of jobs by economic activity, referring to the interval from 2013 to the first quarter of 2021, where a notable negative variation is observed in the period from 2013 to 2015, because of the financial austerity implemented with the troika, which among other measures, promoted early retirements to reduce jobs (Rosa 2020). It should be noted that according to a study conducted by the European European Commission (2020a) on the evolution of the percentage of civil servants over total employment in the period from 2000 to 2018, Portugal remained one of the countries that had the lowest percentage of the EU members, at $14 \%$, with the EU-27 average being $17 \%$. The highest proportions were achieved by the Scandinavian countries (e.g., Sweden (29\%), Denmark $(28 \%)$, and Finland $(24 \%))$, and the lowest by Germany $(11 \%)$.

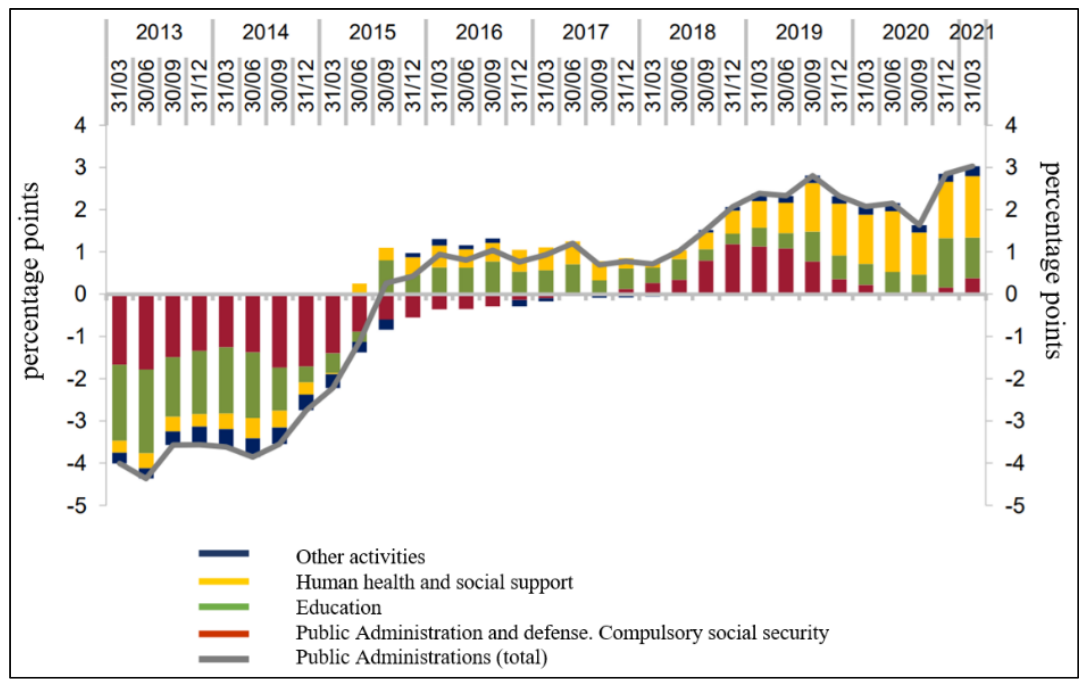

Figure 1. Variation of employment in general government by economic activity in Portugal. Source: DGAEP/DIOEP (position on 31 March 2021).

As for the salaries paid in the Portuguese PA, Rosa (2020) states that the average net monthly remuneration of civil servants was, in 2019, EUR 1095 in the Central Government and EUR 767 in the Local Government, and that, compared to 2010, there was a decrease in purchasing power of $-12.3 \%$ for Central Government employees and $-8.1 \%$ for Local Government employees. 


\subsection{People Management in Public Administration: Behavioural Aspects and Motivation}

Behavioural aspects in the work context have been widely studied for almost a hundred years, since the need for greater humanisation and democratisation of work became urgent, in contrast to the Taylorist and Fordist systems of industrial production, in force since the first and second decade of the twentieth century, respectively. Motivation is represented by a decision-making process that leads the individual to employ his best efforts and competencies to carry out his tasks, with obvious reflexes on productivity and on the performance of companies in any sector of activity.

The first scientific concerns about the influence of the physical conditions of the work environment in industrial productivity emerged in the 1920s in the United States, with the landmark experience of Hawthorne in 1927, in which Mayo (1959) studied the effects of lighting on worker productivity. The greatest contribution of Mayo's work, which gave rise to Human Relations Theory, is the finding that the salary is not the only decisive factor in worker satisfaction and that human beings are motivated by social, symbolic and non-material rewards (Mayo 1959).

Later, in the 1950s, the Behavioural Theory arises, focusing on the study of human motivation. The greatest exponents of this theory are Maslow and Herzberg. It is Maslow's Theory of the Hierarchy of Needs (Maslow 1954), whose representation through a pyramid is quite classic and widespread even today. According to this theory, there are five categories of human needs, which follow a hierarchy of importance: physiological needs, safety needs, social needs, esteem needs and self-actualisation needs. The primary needs, such as physiological and security, occupy the base of the pyramid, and the other needs are tapering down to the top of the pyramid, consisting of self-actualisation in the maximisation of skills and human potential. As the individual is endowed with an innate propensity to seek self-realisation, it can be inferred from this theory that the satisfaction of one or more needs generates a behavioural impulse to satisfy another need in the hierarchical scale (Maslow 1954).

Maslow's work influenced the development of other motivational theories, such as Herzberg's Two-Factor Theory, which constituted an important legacy for studies on job satisfaction. According to Herzberg (1987), the factors that produce satisfaction at work are distinct from those that produce dissatisfaction. The factors capable of producing dissatisfaction are extrinsic and were called hygienic. They comprise company policy and management, interpersonal relations, supervision, working conditions, salary and benefits, status and safety at work. The factors which produce satisfaction are intrinsic and were called motivating - they comprise achievement and recognition, the work itself, the challenge and responsibility, as well as the progress registered or subsequent development attained. According to this theory, the absence of hygienic factors causes demotivation, but their presence is not a motivating element. Only the presence of motivating factors causes job satisfaction (Herzberg 1987).

Although there are differences between the Hierarchy of Needs Theory and the TwoFactor Theory (the main one being that Maslow considers human needs within various spheres of life, whereas Herzberg focuses on the organisational context), it is possible to establish a parallel between the theories, in which Herzberg's hygienic factors correspond to the most basic needs of Maslow's pyramid, and the motivational factors correspond to the needs at the top of the pyramid, as shown in Figure 2. 


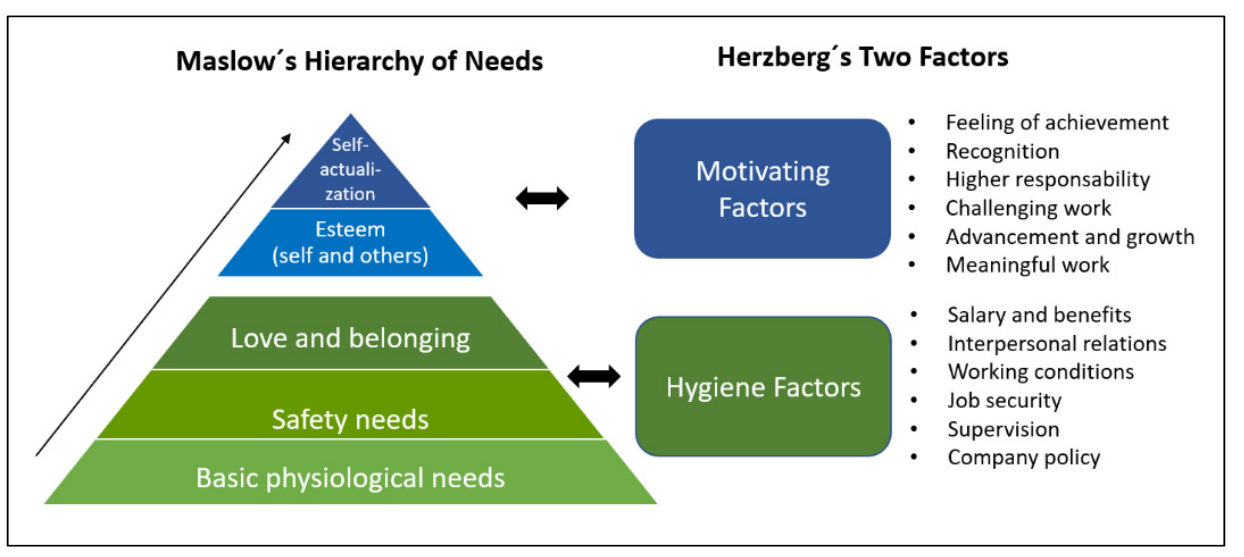

Figure 2. Comparison of Maslow's and Herzberg's theories of motivation. Source: Own elaboration. Adapted from Maslow's and Herzberg's theories.

McGregor (1960) analysed human behaviour at work, inspired by Mayo's studies and the ideas related to the individual work of Taylor's Scientific Administration, Fayol's Classical Theory and Weber's Theory of Bureaucracy, such as the focus on method and production, the imprisonment of creativity and the limitation of individual initiative (Pérez-Ramos 1990; Rodrigues 1994). McGregor (1960) is the author of the antagonistic Theories $\mathrm{X}$ and $\mathrm{Y}$. According to these theories, the work based on scientific management meets the basic needs of the individual but offers little opportunity for satisfaction of individual needs, such as self-esteem and recognition. With these premises, he established Theory $\mathrm{X}$, in which human beings have an aversion to work and are lazy, needing to be coerced, controlled and threatened with punishment to make them strive to achieve the organisation's goals. On the contrary, Theory Y assumes that people want and need to work, aiming at goals to which they commit themselves, and these goals depend on rewards associated with the execution of work.

Another legacy of Maslow in the motivational field is the Acquired Needs Theory by McClelland (1972), who identified the existence of three factors of professional motivation: the need for achievement, the need for affiliation and the need for power. According to this theory, all people are motivated, to a lesser or greater extent, by these three needs, which vary according to personality characteristics, cultural factors and life experience.

The Expectancy Theory by Vroom (1964) is also important for the studies of job satisfaction. According to this theory, which follows a procedural approach, people are motivated for good performance at work if they believe they will be rewarded. The basic parameters in the motivational cycle of employees are expectancy (effort improves performance), instrumentality (performance brings rewards) and valence (rewards are valuable).

The issue of motivation is nowadays widely studied by scholars in the fields of Administration and People Management, who are devoted to conceptualising and measuring the construct of Public Service Motivation (PSM) (Bellé and Ongaro 2014; Ritz 2011; Wright and Grant 2010; Kim 2009; Pandey et al. 2008; Houston 2006; Brewer and Selden 1998; Alonso and Lewis 2001; Crewson 1997; Perry 1996). In the public sector, particularly, motivation is at the core of the debates on behaviour and performance since it is quite challenging to maintain a level of motivation and satisfaction in public employees, who, as a rule, do not have access to the attractions and rewards of the private sector.

On the other hand, bringing public management closer to private management, as has been done since the 1990s with reform measures, does not always generate the desired effects in terms of staff motivation. Bellé and Ongaro (2014) pointed to the decrease in the motivation of civil servants and the loss of the significance of work for a common good following the austere NPM measures implemented in the Italian PA.

In 2015, Madureira and Rodrigues (2015) applied a survey to civil servants of the Portuguese Central PA on a large scale (11,295 respondents) to assess levels and factors 
of motivation. The data collected revealed a high degree of educational attainment $(70 \%$ of respondents with at least a graduate degree). Regarding motivational aspects, only $44 \%$ of the respondents were satisfied with their work, and the level of motivation was even lower ( $36 \%$ of the respondents felt motivated). As for performance evaluation, $88 \%$ of the respondents disagreed with the current evaluation system-SIADAP. Regarding the mission for the common good, $83 \%$ of the workers believed that they had a duty to be accountable to citizens, and $78 \%$ felt good about themselves for performing a public function. Conversely, $80 \%$ of the workers did not feel prestigious or valued by citizens.

Among the factors considered most important for the satisfaction of public workers, which obtained more than $95 \%$ of the choices, were, in descending order: self-satisfaction, salary, possibility of developing stimulating work, transparency in performance evaluations, conviction of working for the common good and autonomy (Madureira and Rodrigues 2015).

In turn, in studies that assessed the motivation and satisfaction of civil servants at the local level, lower levels of educational qualifications were found in the municipalities, ranging from $24.2 \%$ to $51.8 \%$ of employees who have only up to the 9 th grade of basic education (Pedro 2015; Lopes 2012). Pedro (2015) found that employees were more satisfied with the dimensions of interpersonal relationships and work content and less satisfied with the performance appraisal system (SIADAP) and changes in the staff structure. Similarly, Lopes (2012) identified greater importance given to companionship and teamwork, and the variables that obtained the lowest evaluation were the salary, rewards, SIADAP, training actions and computer resources.

In a study conducted with civil servants of a regional laboratory in the Azores about the troika's austerity policy, Fraga (2014) identified the work content, interpersonal relationships and recognition as the most motivating factors. In turn, the most criticised practices were salary reduction, increase in working hours, limitation of career progression and implementation of SIADAP.

\subsection{Innovation in Public Administration}

In the public sector, innovation can be perceived as the successful creation and implementation of new processes, products, services and working methods that result in significant improvements in the results, efficiency, effectiveness and quality of the services provided to the population (Albury 2005).

According to Bekkers et al. (2013), innovation is a concept that inspires people and policy because it offers the promise of radical change. As such, the desire to innovate in the public sector has a history linked to reform programmes aimed at meeting budget reductions, introducing new management and governance ideologies (such as the aforementioned NPM) or adopting new information and communication technologies (ICTs) such as e-Government.

Castro and Guimarães (2019) argue that for the innovation process in the public sector, leadership and entrepreneurial actions performed by employees are essential. Additionally, organisational characteristics also contribute to support entrepreneurial behaviour, which is a requirement for innovation. In turn, public organisations operate within organisational networks that can increase the possibilities of developing and applying innovations (Gieske et al. 2016).

According to Borins (2002), the emergence of innovation prizes in the public sector has stimulated the development and dissemination of innovations and good management practices. The Ministry of the Presidency and Administrative Modernisation, AMA and INA have encouraged measures to promote innovation and entrepreneurship in the Central Administration and at the local authority level, with emphasis on the Laboratory of Experimentation for Innovation in the Public Administration-LabX (2021), involved in the development of innovative projects, such as Balcão Único do Emprego (Single Employment Desk), Balcão do Empreendedor (Entrepreneur's Desk) and Lojas do Cidadão (Citizen's Shops). 


\section{Method}

\subsection{Procedure}

This research was carried out by means of an electronic questionnaire survey, which was made available on the Forms UA platform after approval by the Data Protection Authority of the University of Aveiro. A total of 1119 citizens, residents in Mainland Portugal and in the Autonomous Regions of the Azores and Madeira, participated in this study. The survey sampling was non-probabilistic, convenient, intentional and of snowball typology (Trochim 2000; Bryman and Bell 2015). In order to reach a representative sample of citizens, an effort was made to disseminate the survey at the national level. A total of 8041 people accessed the questionnaire in the period from 8 June to 9 December 2020, and 1119 complete answers were obtained. For an infinite population $(n>100,000)$, the sample obtained with the survey $(n=1119)$ is representative with a $\pm 3 \%$ margin of error, considering a 95\% confidence level (Gil 2017).

\subsection{Survey Instrument}

Figure 3 shows how the survey instrument was developed as a part of a more global doctoral project, led by the first author of this study, which involves the research of three related subjects: the application of European funds, PA and e-Government in Portugal. A focus group, interviews with experts in the field and a literature review led to the development of the survey questions. The literature review on the PA in Portugal involved public sector reforms as well as innovation [or change for the better], motivation and the image of the PA; bureaucracy in the PA; and the "Loja do Cidadão" (Citizens' shop) since it is an institution that concentrates a variety of public services. Portuguese PA has not been the object of much previous research, leaving a gap in the literature that we wish to fill. In order to illustrate this, we have carried out a search in the Scopus database on 8 August 2021, using Boolean operators: "public administration" and "Portugal" and "government", which resulted in 62 documents. We then reapplied the same search, replacing Portugal with Germany and Spain, which resulted in 144 documents and 198 documents, respectively.

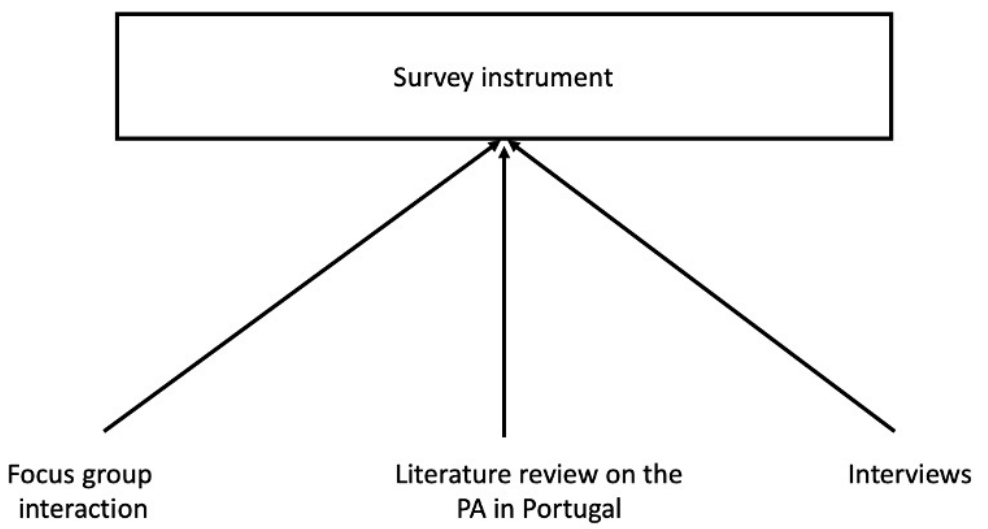

Figure 3. The development of the survey instrument. Source: Own elaboration.

The survey instrument was composed of 30 questions in its entirety, six of which were related to socio-demographic data. For this study, we worked with a set of eight questions specific to Portuguese PA (among which seven closed questions and one semi-structured optional question). This set of questions, approached for the first time, is displayed in Appendix A, Table A1.

\subsection{Research Hypotheses}

The survey was answered by 1119 citizens, of whom 329 are civil servants (among occupants of technical and administrative functions and management positions). In view of the significant percentage of these workers $(29.4 \%)$ in the sample, we were able to ascertain 
whether there are differences in the evaluation of PA aspects under study between two groups: respondents who are civil servants and respondents from other sectors (61.6\%). Then, the following research hypotheses were formulated:

Hypothesis 1 (H1). The sector of activity (public or other sectors) has a significant effect on the perception of the existence of bureaucracy in $P A$, and this perception is expected to be higher in other sectors of activity than in the public sector.

Hypothesis 2 (H2). The opinion on the number of civil servants in public administration is not independent of the sector of activity (public or other sectors) to which the participant belongs, and it is expected that participants who carry out their activity in other sectors have a higher perception of excess civil servants in PA than those who are in the public sector.

Hypothesis 3 (H3). The activity sector (public or gold sector) has a significant effect on the perceived efficiency, qualification, commitment, ethics and motivation of public administration employees, and it is expected that this perception is higher in participants who work in the public sector.

Hypothesis 4 (H4). The sector of activity (public or other sectors) has a significant effect on whether the participant is in favour of the recognition of PA employees, with participants with activity in the public sector expected to be more favourable with regard to the existence of this recognition.

Hypothesis 5 (H5). The sector of activity (public or other sectors) has a significant effect on the evaluation of quality in customer service in the Loja do Cidadão [Citizens' Shop], and it is expected that, among the participants who have been in a citizen shop, the participants who perform functions in the public sector evaluate the service better than the other participants.

\subsection{Data Analysis Procedure}

After collecting the data electronically, the IBM SPSS Statistics 25 software was used for the descriptive statistical analyses, as well as for the application of the chi-square test and the non-parametric Mann-Whitney $U$ tests. The semi-structured question "What would you change in Public Administration if you could?" was dealt with using MAXQDA Analytics Pro20 software.

\section{Results}

\subsection{Participants' Profile}

All study participants were aged 18 years or over, with $129(11.5 \%)$ aged $18-22$ years, $127(11.3 \%)$ aged $23-29$ years, $106(9.5 \%)$ aged $30-36$ years, $211(18.9 \%)$ aged $37-43$ years, $230(20.6 \%)$ aged $44-50$ years, $173(15.5 \%)$ aged $51-57$ years, $101(9 \%)$ aged $58-64$ years, 31 (2.8\%) aged $65-70$ years and $11(1 \%)$ being older than 70 years.

With regard to gender, $585(52.3 \%)$ participants belonged to the female gender, 529 $(47.3 \%)$ to the male gender and $5(0.4 \%)$ to another gender.

In terms of nationality, 1080 (96.5\%) participants were of Portuguese nationality and $39(3.5 \%)$ of other nationalities. For the latter, the most representative nationality was Brazilian (46.2\%), followed by Spanish (7.7\%). There were participants living in all the districts of mainland Portugal and the Autonomous Regions of Madeira and Azores, with the largest percentage living in the districts of Aveiro (17.2\%), Lisbon (13.7\%) and Porto $(11.2 \%)$.

Regarding completed educational qualifications, $9(0.8 \%)$ of the participants had up to the third cycle of basic education, $136(12.2 \%)$ had secondary education, $88(7.9 \%)$ university attendance, $293(26.2 \%)$ a graduation degree, $316(28.2 \%)$ the postgraduate or master degree, $219(19.6 \%)$ the doctoral degree, $31(2.8 \%)$ a post-doctorate, $23(2.1 \%)$ a habilitation qualification and $4(0.4 \%)$ fell into another level of education. 
In terms of profession, $209(18.7 \%)$ were students, $289(25.9 \%)$ were teachers, $58(5.2 \%)$ were researchers, $329(29.4 \%)$ were civil servants (including technical, administrative and managerial positions), $140(12.5 \%)$ were employees in the private sector, $38(3.4 \%)$ were self-employed, $11(1 \%)$ were unemployed, $20(1.8 \%)$ were retired, and $25(2.2 \%)$ had another profession.

\subsection{Descriptive Statistics}

The first question asked to the participants was "how bureaucratic do you think the Portuguese Public Administration is?", to which one (0.1\%) participant answered not at all bureaucratic, $23(2.1 \%)$ answered a little bureaucratic, $222(19.8 \%)$ answered moderately bureaucratic, $538(48.1 \%)$ answered quite bureaucratic and $335(29.9 \%)$ answered very bureaucratic.

Next, the participants were asked, "what is your opinion on the number of civil servants in the PA Bodies?" In total, 146 (13\%) participants considered that there were too few civil servants, $64(5.7 \%)$ thought that the number of civil servants was adequate, $99(8.8 \%)$ considered that there were too many civil servants, 725 (64.8\%) perceived that the number of civil servants was not well distributed and that there were both shortages and excesses in different areas. In total, 85 (7.6\%) participants had no opinion on the matter.

The following question was "On a scale of 1 (very bad) to 5 (excellent), how do you evaluate the image of the civil servant, in relation to: efficiency; qualification; commitment; ethics; and motivation". According to Scheme 1, it can be observed that the variable that received the worst evaluation was motivation, with $59.2 \%$ of the participants evaluating it as very bad or bad.

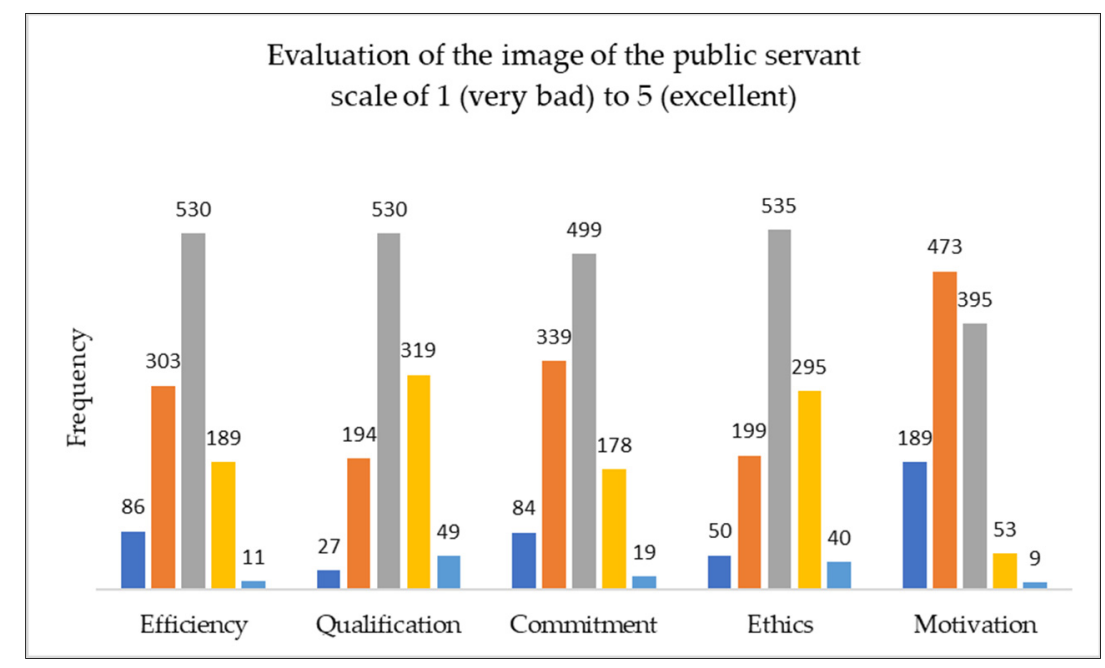

Scheme 1. Evaluation of the image of the civil servant. Source: Own elaboration.

The other variables obtained a mostly average assessment ( $47.4 \%$ for efficiency and qualification, $44.6 \%$ for commitment and $47.8 \%$ for ethics). The variable qualification was the one that received the best positive evaluation ( $32.9 \%$ considered it good or excellent), followed by ethics ( $30 \%$ of good or excellent evaluation).

Asked whether "they are in favour of recognising the work of the individual in the civil service (which includes monetary awards and merit diplomas, among others)", 71 (6.3\%) participants did not agree at all, $158(14.1 \%)$ agreed in part, $230(20.6 \%)$ agreed moderately, $331(29.6 \%)$ agreed quite a lot and $329(29.4 \%)$ strongly agreed.

The vast majority of participants $(87 \%)$ have already been in a Loja do Cidadão (Citizen's Shop). These participants $(n=974)$ were then asked about "the quality of service provided in the Citizen's Shop". Eight participants evaluated it as very bad $(0.9 \%), 93$ as bad $(9.5 \%), 406$ as reasonable (41.7\%), 430 as good (44.1\%) and 37 as excellent $(3.8 \%)$. 
The question "do you believe it is possible to innovate in the Public Administration?" obtained 1041 affirmative answers (corresponding to $93 \%$ of the sample). Moreover, 32 negative answers ( $2.9 \%$ of the sample) were received, and 46 ( $4.1 \%$ of the sample) were not sure.

Table 3 consolidates the results of the descriptive statistics for the survey questions presented in this subsection.

Table 3. Descriptive statistics of the survey questions on Portuguese PA.

\begin{tabular}{|c|c|c|c|c|}
\hline \multicolumn{2}{|c|}{ Questions } & Answers & Frequency & Percentage \\
\hline \multirow{5}{*}{\multicolumn{2}{|c|}{$\begin{array}{l}\text { How bureaucratic do you believe the Public } \\
\text { Administration is? }\end{array}$}} & Not at all bureaucratic & 1 & $0.1 \%$ \\
\hline & & A little bureaucratic & 23 & $2.1 \%$ \\
\hline & & Moderately bureaucratic & 222 & $19.8 \%$ \\
\hline & & Extremely bureaucratic & 538 & $48.1 \%$ \\
\hline & & Very bureaucratic & 335 & $29.9 \%$ \\
\hline \multirow{5}{*}{\multicolumn{2}{|c|}{$\begin{array}{l}\text { What is your opinion on the number of civil } \\
\text { servants in Public Administration Bodies? }\end{array}$}} & I don't have a fixed opinion & 85 & $7.6 \%$ \\
\hline & & There are few employees & 146 & $13.0 \%$ \\
\hline & & The number of employees is adequate & 64 & $5.7 \%$ \\
\hline & & There are too many employees & 99 & $8.8 \%$ \\
\hline & & $\begin{array}{l}\text { It is not well distributed and there are both } \\
\text { shortages and excesses in different areas }\end{array}$ & 725 & $64.8 \%$ \\
\hline \multirow{25}{*}{$\begin{array}{l}\text { On a scale of } 1 \text { (very bad) } \\
\text { to } 5 \text { (excellent), how do you } \\
\text { evaluate the image of the } \\
\text { civil servant, in relation to: }\end{array}$} & \multirow{5}{*}{ Efficiency } & Very Bad & 86 & $7.7 \%$ \\
\hline & & Bad & 303 & $27.1 \%$ \\
\hline & & Fair & 530 & $47.4 \%$ \\
\hline & & Good & 189 & $16.9 \%$ \\
\hline & & Excellent & 11 & $1.0 \%$ \\
\hline & \multirow{5}{*}{ Qualification } & Very Bad & 27 & $2.4 \%$ \\
\hline & & Bad & 194 & $17.3 \%$ \\
\hline & & Fair & 530 & $47.4 \%$ \\
\hline & & Good & 319 & $28.5 \%$ \\
\hline & & Excellent & 49 & $4.4 \%$ \\
\hline & \multirow{5}{*}{ Motivation } & Very Bad & 189 & $16.9 \%$ \\
\hline & & Bad & 473 & $42.3 \%$ \\
\hline & & Fair & 395 & $35.3 \%$ \\
\hline & & Good & 53 & $4.7 \%$ \\
\hline & & Excellent & 9 & $0.8 \%$ \\
\hline & \multirow{5}{*}{ Commitment } & Very Bad & 84 & $7.5 \%$ \\
\hline & & Bad & 339 & $30.3 \%$ \\
\hline & & Fair & 499 & $44.6 \%$ \\
\hline & & Good & 178 & $15.9 \%$ \\
\hline & & Excellent & 19 & $1.7 \%$ \\
\hline & \multirow{5}{*}{ Ethics } & Very Bad & 50 & $4.5 \%$ \\
\hline & & Bad & 199 & $17.8 \%$ \\
\hline & & Fair & 535 & $47.8 \%$ \\
\hline & & Good & 295 & $26.4 \%$ \\
\hline & & Excellent & 40 & $3.6 \%$ \\
\hline \multirow{5}{*}{\multicolumn{2}{|c|}{$\begin{array}{l}\text { Are you in favour of recognising the work of } \\
\text { the individual in the civil service (monetary } \\
\text { awards and diplomas of merit, etc)? }\end{array}$}} & Do not agree at all & 71 & $6.3 \%$ \\
\hline & & Agree in part & 158 & $14.1 \%$ \\
\hline & & Moderately agree & 230 & $20.6 \%$ \\
\hline & & Agree quite a lot & 331 & $29.6 \%$ \\
\hline & & Strongly agree & 329 & $29.4 \%$ \\
\hline \multirow{2}{*}{\multicolumn{2}{|c|}{$\begin{array}{l}\text { Have you ever been to a Loja do Cidadão? } \\
\text { (Citizens' Shop) }\end{array}$}} & Yes & 974 & $87 \%$ \\
\hline & & No & 145 & $13 \%$ \\
\hline \multirow{5}{*}{\multicolumn{2}{|c|}{$\begin{array}{l}\text { How do you rate the quality of the service you } \\
\text { sought in the Citizens' Shop? }\end{array}$}} & Very bad & 8 & $0.8 \%$ \\
\hline & & Bad & 93 & $9.5 \%$ \\
\hline & & Reasonable & 406 & $41.7 \%$ \\
\hline & & Good & 430 & $44.1 \%$ \\
\hline & & Excellent & 37 & $3.8 \%$ \\
\hline
\end{tabular}




\subsection{Hypotheses Validation}

In order to inspect whether there are differences of opinion between the public sector and other sectors regarding the degree of the bureaucracy of the Portuguese PA, Hypothesis 1 was tested by the Mann-Whitney non-parametric test, since the dependent variable is ordinal (from 1 "Not at all bureaucratic" to 5 "Very bureaucratic").

The results indicate that the activity sector has a significant effect on the perception of the existence of bureaucracy in public administration $(Z=-2.56 ; p=0.010)$, with participants from other sectors revealing a higher perception of the existence of bureaucracy than participants from the public sector (Table 4). Thus, Hypothesis 1 was confirmed.

Table 4. Effect of sector on the perception of the existence of bureaucracy in the Public Administration.

\begin{tabular}{cccccc}
\hline \multirow{2}{*}{ Mann-Whitney U } & $\begin{array}{c}\text { Standardised } \\
\text { Test Statistic }\end{array}$ & $p$ & \multicolumn{2}{c}{ Mean Rank } \\
\cline { 3 - 5 } & & & $\begin{array}{c}\text { Other Sectors } \\
(\boldsymbol{n}=\mathbf{7 9 0})\end{array}$ & $\begin{array}{c}\text { Public Sector } \\
(\boldsymbol{n}=\mathbf{3 2 9})\end{array}$ \\
\hline $118,302.00$ & -2.56 & 0.010 & 574.75 & 524.58 \\
\hline
\end{tabular}

Source: Own elaboration.

To elucidate whether there are differences of opinion between the public sector and other sectors regarding the number of civil servants in the Portuguese PA, Hypothesis 2 was tested by a chi-square test.

The opinion about the number of civil servants in PA is not independent of the sector of activity (public or other sectors) $\left(\mathrm{x}^{2}(4)=41.18 ; p<0.001\right)$. The perception that there are too many civil servants in PA is higher among the participants who work in other sectors, but regarding the poor distribution of the number of civil servants across areas, the perception of the participants who work in the public sector is higher than that of those who work in other sectors (Table 5). Consequently, Hypothesis 2 was confirmed.

Table 5. What is your opinion on the number of civil servants in PA Bodies? Professional Sector Crosstabulation.

\begin{tabular}{|c|c|c|c|c|}
\hline & & \multicolumn{2}{|c|}{ Professional Sector } & \multirow{2}{*}{ Total } \\
\hline & & Other Sectors & Public Sector & \\
\hline \multirow{5}{*}{$\begin{array}{l}\text { What is your opinion } \\
\text { on the number of civil } \\
\text { servants in PA Bodies? }\end{array}$} & I don't have a fixed opinion & $\begin{array}{c}75 \\
9.5 \%\end{array}$ & $\begin{array}{c}10 \\
3.0 \%\end{array}$ & $\begin{array}{c}85 \\
7.6 \%\end{array}$ \\
\hline & There are few employees & $\begin{array}{c}108 \\
13.7 \%\end{array}$ & $\begin{array}{c}38 \\
11.6 \%\end{array}$ & $\begin{array}{c}146 \\
13.0 \%\end{array}$ \\
\hline & The number of employees is adequate & $\begin{array}{c}48 \\
6.1 \%\end{array}$ & $\begin{array}{c}16 \\
4.9 \%\end{array}$ & $\begin{array}{c}64 \\
5.7 \%\end{array}$ \\
\hline & There are too many employees & $\begin{array}{c}88 \\
11.1 \%\end{array}$ & $\begin{array}{c}11 \\
3.3 \%\end{array}$ & $\begin{array}{c}99 \\
8.8 \%\end{array}$ \\
\hline & $\begin{array}{l}\text { It is not well distributed, and there is both } \\
\text { a shortage and excess in different areas }\end{array}$ & $\begin{array}{c}471 \\
59.6 \%\end{array}$ & $\begin{array}{c}254 \\
77.2 \%\end{array}$ & $\begin{array}{c}725 \\
64.8 \%\end{array}$ \\
\hline & Total & $\begin{array}{c}790 \\
100.0 \%\end{array}$ & $\begin{array}{c}329 \\
100.0 \%\end{array}$ & $\begin{array}{c}1119 \\
100.0 \%\end{array}$ \\
\hline
\end{tabular}

Source: Own elaboration.

In order to ascertain whether there are different perceptions between the public sector and other sectors about the skills and attitudes under analysis, Hypothesis 3 was tested, through five non-parametric Mann-Whitney tests, since the dependent variable is ordinal (from 1 "Very bad" to 5 "Excellent").

The results indicate that the activity sector has a significant effect on the perception of efficiency $(Z=4.44 ; p<0.001)$, qualification $(Z=3.61 ; p<0.001)$, commitment $(Z=4.28$; $p<0.001)$ and ethics $(Z=3.98 ; p<0.001)$, with participants who work in the public sector 
having a higher perception than participants who work in other sectors (Table 6). With regards to the perception of motivation $(Z=1.69 ; p=0.092)$, no statistically significant differences were found between participants from both sectors. Hypothesis 3 was hence validated, except for the variable motivation.

Table 6. Effect of activity sector on the perception of skills and attitudes of civil service employees.

\begin{tabular}{|c|c|c|c|c|c|}
\hline \multirow{2}{*}{$\begin{array}{c}\text { Dependent } \\
\text { Variable }\end{array}$} & \multirow{2}{*}{$\begin{array}{c}\text { Mann- } \\
\text { Whitney U }\end{array}$} & \multirow{2}{*}{$\begin{array}{l}\text { Standardised } \\
\text { Test Statistic }\end{array}$} & \multirow[b]{2}{*}{$p$} & \multicolumn{2}{|c|}{ Mean Rank } \\
\hline & & & & $\begin{array}{l}\text { Other Sectors } \\
\quad(n=790)\end{array}$ & $\begin{array}{l}\text { Public Sector } \\
\quad(n=329)\end{array}$ \\
\hline Efficiency & $150,349.00$ & $4.44^{* * *}$ & $<0.001$ & 534.18 & 621.99 \\
\hline Qualification & $146,495.50$ & $3.61^{* * *}$ & $<0.001$ & 539.06 & 610.28 \\
\hline Commitment & $149,701.50$ & $4.28 * * *$ & $<0.001$ & 535.00 & 620.02 \\
\hline Ethics & $148,185.00$ & $3.98 * * *$ & $<0.001$ & 536.92 & 615.41 \\
\hline Motivation & $137,721.00$ & 1.69 & 0.092 & 550.17 & 583.60 \\
\hline
\end{tabular}

Note: ${ }^{* * *} p<0.001$. Source: Own elaboration.

Aiming to ascertain whether the sector of activity (public or other) is interlinked with a greater appreciation of recognition of civil servants, Hypothesis 4 was tested, by five non-parametric Mann-Whitney tests, since the dependent variable is ordinal (from 1 "I do not agree at all" to 5 "I strongly agree").

The results indicate that the sector of activity has a significant effect on whether the participant is in favour of recognising civil servants $(Z=2.87 ; p=0.004)$, with participants who work in the public sector being more in favour of recognising civil servants than participants who work in other sectors (Table 7). Hypothesis 4 was thus validated.

Table 7. Effect of activity sector on recognition agreement of public administration employees.

\begin{tabular}{cccccc}
\hline \multirow{2}{*}{ Mann-Whitney U } & $\begin{array}{c}\text { Standardised } \\
\text { Test Statistic }\end{array}$ & $p$ & \multicolumn{2}{c}{ Mean Rank } \\
\cline { 4 - 5 } & 2.87 & 0.004 & $\begin{array}{c}\text { Other Sectors } \\
(\boldsymbol{n}=\mathbf{7 9 0})\end{array}$ & $\begin{array}{c}\text { Public Sector } \\
(\boldsymbol{n}=\mathbf{3 2 9})\end{array}$ \\
\hline $143,619.50$ & & 542.70 & 601.53 \\
\hline
\end{tabular}

Source: Own elaboration.

With the aim of identifying differences in appreciation of the quality of service provided in the Citizens' Shop between the public sector and other sectors, Hypothesis 5 was tested, whereby five non-parametric Mann-Whitney tests were performed, since the dependent variable is ordinal (from 1 "Very bad" to 5 "Excellent").

The results indicate that the activity sector has a significant effect on the evaluation of the quality of customer service in the citizen shop $(Z=3.50 ; p<0.001)$, with participants who work in the public sector having a better perception of customer service in the Loja do Cidadão than participants who work in other sectors (Table 8). Hypothesis 5 was confirmed.

Table 8. Effect of the activity sector in the evaluation of the public service in the citizen shop.

\begin{tabular}{|c|c|c|c|c|}
\hline \multirow[b]{2}{*}{ Mann-Whitney U } & \multirow{2}{*}{$\begin{array}{l}\text { Standardised } \\
\text { Test Statistic }\end{array}$} & \multirow[b]{2}{*}{$p$} & \multicolumn{2}{|c|}{ Mean Rank } \\
\hline & & & $\begin{array}{l}\text { Other Sectors } \\
\quad(n=790)\end{array}$ & $\begin{array}{l}\text { Public Sector } \\
\quad(n=329)\end{array}$ \\
\hline $108,353.50$ & 3.50 & $<0.001$ & 469.43 & 533.90 \\
\hline
\end{tabular}

Source: Own elaboration.

\subsection{Qualitative Analysis}

The question "What would you change in the Public Administration if you could?" was semi-structured and optional and obtained 480 valid answers. Due to the qualitative 
nature of the question, it received data treatment using the MAXQDA Analytics Pro20 Software. The participants' comments generated a total of 4620 different words. By restricting these words to nouns, adjectives, intensity adverbs and verbs (except modals) and grouping those of the same root (for instance, the words bureaucracy and bureaucratic were grouped in bureaucracy), a word cloud was generated (Figure 4), with the words that had at least eight frequencies. One can observe the predominance of the word "more", evidencing that something is lacking in the PA. Other highlighted words are "bureaucracy", "services", "public" and "work".

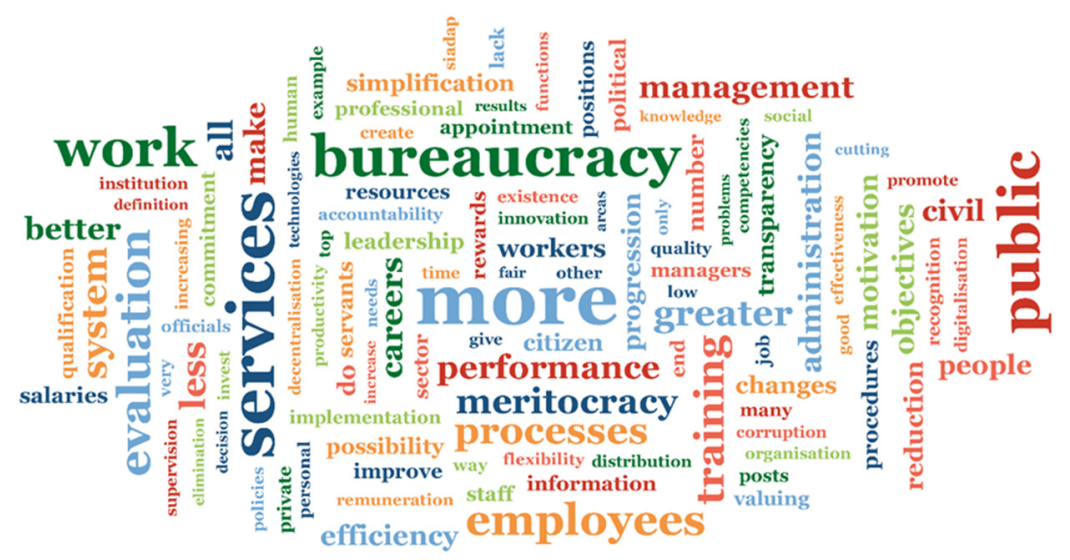

Figure 4. Word cloud on the question "What would you change in PA if you could"? Source: Own elaboration (MAXQDA Analytics Pro20).

Next, a two-word combination function was applied to the text of the comments, which resulted in 117 different combinations (Figure 5). The combinations "less bureaucracy", "public administration", "performance evaluation", "career progression" and "civil servants" predominate.

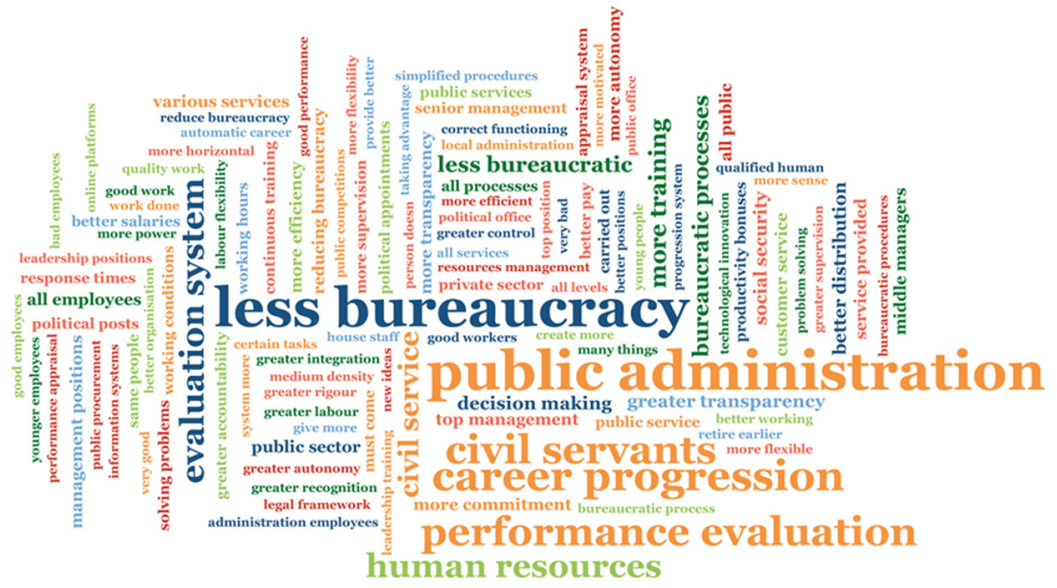

Figure 5. Cloud of the combination of two words to the question "What would you change in PA if you could?" Source: Own elaboration (MAXQDA Analytics Pro20).

The spreadsheet with respondent comments was compiled using as a unit for frequency analysis the distinct opinions emanated, grouped by similarity $(n=298)$. Table 9 presents the analysis-of-opinions frequency in the case of 10 or more occurrences $(n=23$, in total). 
Table 9. Frequency analysis of opinions of the question "What would you change in the PA?".

\begin{tabular}{|c|c|}
\hline Opinions & Frequency \\
\hline Reducing bureaucracy in the processes/decreasing bureaucracy in Public Administration & 83 \\
\hline $\begin{array}{l}\text { Institution of meritocracy/award of incentives and prizes for merit and productivity/better salaries and } \\
\text { positions for the most productive, assiduous and ethical employees }\end{array}$ & 77 \\
\hline $\begin{array}{c}\text { Implementation of a fair, transparent and effective performance evaluation based on results/an evaluation } \\
\text { system other than SIADAP }\end{array}$ & 64 \\
\hline Compulsory continuous training with career consequences & 32 \\
\hline $\begin{array}{l}\text { Elimination of the partisanisation and politicisation of public office/political appointments/political } \\
\text { servility/"jobs for the boys" }\end{array}$ & 32 \\
\hline Increasing the efficiency, efficacy and quality of the services provided and of PA bodies & 31 \\
\hline Implementation of measures to improve motivation and personal satisfaction (rewards) & 27 \\
\hline Work by objectives and targets & 25 \\
\hline $\begin{array}{l}\text { Possibility of dismissal if the person does not have the skills for the position/penalising those who fail and } \\
\text { perform poorly }\end{array}$ & 24 \\
\hline Dematerialisation/more digitalisation/too much paperwork/too many documents printed & 20 \\
\hline Simplification of processes and procedures & 20 \\
\hline $\begin{array}{c}\text { Greater integration and articulation of the services provided and databases/interoperability/cross-linking of } \\
\text { data between systems }\end{array}$ & 17 \\
\hline Improvement in customer service and treating people with politeness and friendliness & 17 \\
\hline Career development possibilities & 16 \\
\hline Valuing and recognising employees & 15 \\
\hline $\begin{array}{c}\text { Better prepared and specialised leadership/training for managers in the areas of behaviour, leadership and } \\
\text { conflict management }\end{array}$ & 14 \\
\hline Equitable distribution of HR according to the needs of the contexts/staff ratios according to the type of service & 14 \\
\hline Automation and computerisation to the maximum (online services) to free up staff for customer service & 12 \\
\hline $\begin{array}{l}\text { Benefiting from access to public positions through friendships/clientelism/"cunhas"/cronyism, without } \\
\text { having the competencies for the position }\end{array}$ & 11 \\
\hline Implementation of measures to improve commitment and engagement & 10 \\
\hline Greater scrutiny in the fight against corruption and fraud & 10 \\
\hline Giving employees responsibility & 10 \\
\hline Streamlining of procedures/speed & 10 \\
\hline
\end{tabular}

Source: Own elaboration.

The most frequent comments relate to the need to reduce the existing bureaucracy in the PA, the institution of a meritocratic system that encourages the most productive employees, and the implementation of a new performance assessment system that is more transparent and effective than the current SIADAP. The need for continuous training and capacity building of employees and managers is also highlighted. The importance given to the current party politicisation in the nomination of management positions, as well as the influences of the social environment, such as friendships, exchange of favours, etc., should be highlighted. Finally, the need to improve the motivation, commitment and prestige of the staff is also quite recurrent.

In order to illustrate the content of the answers about the needs for change in the Public Administration, the 52 most frequent comments were grouped into 14 areas, as shown in Scheme 2. Standing out, tied, are the needs for debureaucratisation and simplification of processes, and implementation of a meritocratic system, which rewards or penalises employees according to their effort and performance. 


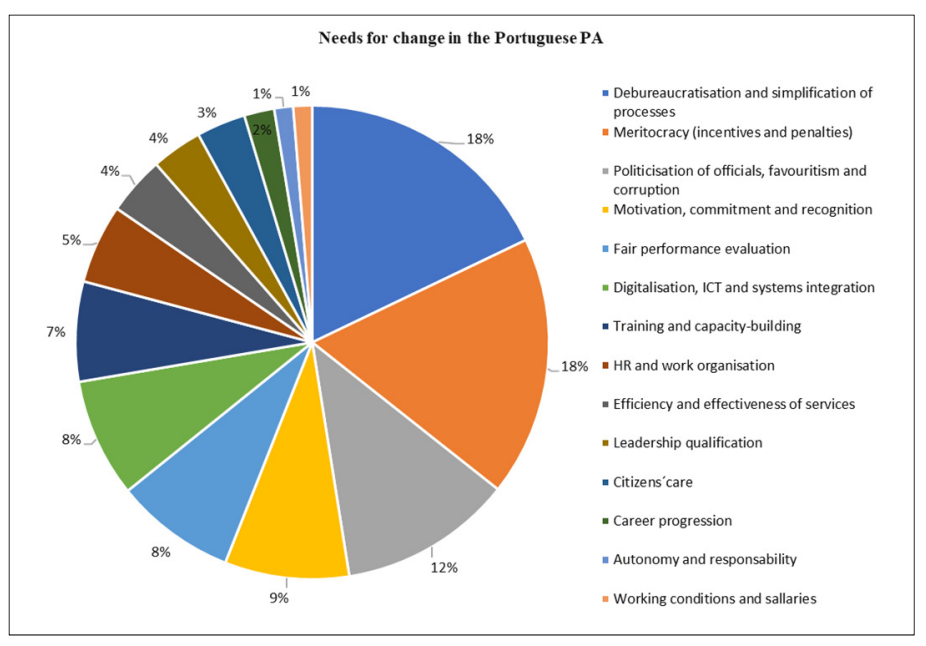

Scheme 2. Needs for change in the Portuguese PA by categories.

\section{Discussion-Organisational Culture-The Public Sector vs. the Private Sector}

The results of the study allow us to state that the Portuguese PA presents high levels of bureaucracy ( $78 \%$ of the respondents considered the PA to be quite or very bureaucratic). This result is corroborated by the most recurrent comment in the spontaneous answers regarding the semi-structured question "what would change in the PA": reducing bureaucracy $(n=83)$. In fact, despite the movements to bring public management closer to private management, advocated by the NPM in recent decades, the Portuguese PA still seems to be structured very much on Weberian concepts of rationality and control (Weber 2000). Curiously (given that according to Ferraz (2020), the bureaucratic model rewards merit), the comments of the respondents highlight the lack of a meritocratic culture in the selection of management positions and in the performance evaluation of civil servants, prevailing partisan appointments, exchanges of favours, the culture of "jobs for the boys" - a practice rooted in the State apparatus to compensate partisan loyalties with appointments of positions and to thus guarantee the control of the State machine (EcoSapo 2021).

In this regard, of a strong component of politicisation of management positions found in the study, in addition to the hiring based on the culture of relationships, which sometimes deviate from the principles of meritocracy in the choice of leaders (namely when they do not have the expected competencies for the position), our findings do not converge with the study of Ferraz (2020), which investigated the factors that influenced the selection of top and middle managers of the Portuguese Central PA $(n=964)$ during the period from 2004 to 2011. Although the study confirmed the inexistence of factors guided exclusively by merit, the factors associated with the professional component (such as area of specialisation and similar functions performed previously in the PA) outweighed the political factors (including political ideology and party affiliation) in the selection of leaders.

With regard to the corruption in the PA, commented on by some respondents, the latest assessment by Transparency International Transparency International Portugal (2021) maintains Portugal in 30th position in a ranking of 180 countries. The score goes from 0 (country perceived as very corrupt) to 100 (very transparent country). Portugal obtained 62 points, two points less than in the previous evaluation, and four points below the EU average. In the first position are Denmark and New Zealand, tied with 87 points. According to the data of the Global Corruption Barometer 2021, also released by Transparency International Transparency International Portugal (2021), 88\% of the Portuguese believe that there is corruption within the government itself, and $41 \%$ think that it has increased in the last year. Regarding the PA, $63 \%$ of the Portuguese believe that the central and local administration is captured by corporate and private interests.

Concerning the digitalisation of services and ICT improvements, this seems to be the dimension where the Portuguese PA has advanced the most in its modernisation and technological innovation strategy. Conversely, as mentioned in the comments $(n=17)$, 
problems of interoperability and integration between systems still persist, hindering the flow of procedures and information. Some studies attribute fundamental importance to the development of interoperability for the consolidation of e-Government in Portugal (Nishimura and Au-Yong-Oliveira 2021; European Commission 2020b; Dias 2016; Marques 2016; Polónia et al. 2014; Gouveia 2009).

Regarding the quantity of existing human resources in public administrations, the opinion that they are not well distributed prevails ( $64.8 \%$ of the respondents), with both a shortage and an excess in different areas. This perception was greater among respondents who are civil servants $(77.2 \%)$ and is corroborated by the comments that there is no equitable distribution of human resources according to needs $(n=14)$, overloading some sectors. On the other hand, the appreciation that there are too many civil servants was 3.5 times higher among respondents from other sectors.

As for the evaluation of the image of the civil servants, it was predominantly at a medium point for the variables of efficiency, qualification (both with $47.4 \%$ ) and ethics $(47.8 \%)$. Commitment and motivation seem to be the key points of weakness in the public sector, especially motivation. Commitment was perceived as very bad or bad by $37.8 \%$ of the respondents, just below reasonable (44.6\%). Motivation was perceived as very bad or bad by $59.2 \%$ of the respondents. Only $5.5 \%$ considered the motivation of civil servants as good or excellent.

According to Alves et al. (2020), affective commitment is driven by positive feelings towards the organisation, and if the employee feels comfortable and confident in an organisation as if it was his family, this creates a personal meaning and a sense of belonging. When this happens, the employee will be more enthusiastic about his work and performance. Due to the low levels of motivation and commitment of civil servants found in our study, one question remains: do civil servants find in the Portuguese Public Administration a welcoming environment, conducive to the development of their potential?

The issue of the wage gap seems to be central to the loss of motivation of public employees and promotes a stampede of professionals to the private sector, and even abroad, in search of better salaries and career progression. As recently reported in the media (Executive Digest Sapo 2021; RTP 2021), Portugal has lost 800 doctors of the National Health Service since the beginning of the COVID-19 pandemic, in addition to other health professionals, such as nurses and radiology technicians. According to Rosa (2020), it was precisely the category of doctors that suffered the greatest fall in purchasing power in relation to net remuneration between 2011 and 2020.

Surprisingly, $59 \%$ of the respondents were in favour of recognising civil servants by means of monetary prizes, diplomas of merit or other awards (this appreciation being higher among civil servants). This finding is in line with the spontaneous comments, which ask for the institution of a meritocratic system with the attribution of awards to the best employees; and the implementation of measures to improve personal satisfaction.

Furthermore, the respondents' appreciation of the services provided at the Loja do Cidadão was surprisingly positive. A total of $47.9 \%$ evaluated it as good or excellent, a higher percentage than those who evaluated it as reasonable (41.7\%). Only $10.4 \%$ of the respondents rated the service as very bad or bad. Even so, the spontaneous comments pointed to the need to increase the efficiency and quality of the services provided and to treat citizens in a more polite and friendly way.

It seems to be consensual that it is possible to innovate in the PA ( $93 \%$ of the respondents consider that it is), which may be in line with the policies adopted by the Government for innovation in the public sector (Borins 2002; LabX 2021).

It is strange, but perhaps understandable, that people in the private sector perceive that the public sector is "over-crowded", with too many human resources for the tasks which need to be performed, making it thus inefficient; the public sector is also perceived as being very bureaucratic and providing a poor service, by those not in the public sector. On the other hand, the public sector perceives itself as being more efficient and as providing a better service to its service users and citizens (public service is perceived as being better by 
those who work in the public sector). Furthermore, the public sector perhaps perceives the private sector as having too much freedom and financial resources, which they use to corrupt people and (public) institutions in their favour and for business purposes.

According to the definition of culture-which people in a group must and will share (House et al. 2004)—so as to be able to work together and understand each other as if using a common "language" made up of beliefs, values and artefacts, we see two large and specific groups co-existing in society (public sector and non-public sector), and both may be right, in their own way. Hence, "the collective programming of the mind that distinguishes the members of one group or category of people from another" (Hofstede 2001, p. 9) is very evident in our study. The notion and importance of culture come again to the forefront, much as was the case in the 1990s, albeit with the knowledge since popularised that changing culture (and mindsets) is extremely difficult and takes a long time-50-100 years in terms of national culture change (Hofstede 2001) and perhaps 25 years to change the culture of an organisation (Schein 1992). To bring these two groups closer together (public and non-public sector) for greater and more harmonic understandings, much communication will have to be done from both sides. However, there is no guarantee that such an initiative would be successful. The success could be measured as having salaries on a more equal basis (currently lower in the public sector) and with work hours as being more similar (currently higher in the private sector). Therefore, as the status quo currently stands, the public sector is seen to work shorter hours (their main benefit), and the non-public sector as having higher salaries (their "perk", so to speak).

A greater balance is needed in order to bring the two sectors closer, and specifically to improve the motivation felt by the public sector, which is low, even in the eyes of the civil servants themselves. As financial bonuses are not possible in the public sector, other methods are necessary to motivate employees. Methods such as giving recognition, involving in decision making, keeping them close and listening to their views and suggestions are ways that senior leadership may motivate civil servants. Perhaps leadership roles require further training in order to eliminate the motivation problem in the public sector. Albeit, without career progression, the public sector may perhaps not be able to eliminate the lack of motivation currently felt amongst its members. Improved job design, as opposed to Taylorism-namely, "pay is the sole motivator for otherwise lazy and unmotivated workers" (King and Lawley 2016, p. 326) - may be a solution for the public sector. As we have seen with Herzberg (1987), job factors that lead to extreme satisfaction include growth, advancement, responsibility, work itself, recognition and achievement. Perhaps the Portuguese public sector has much to learn from older models, which remain relevant, even today.

\section{Conclusions and Final Considerations}

We perceive that our study has reached the proposed objectives, and its findings add to the corollary of contributions from theoretical and experimental research on such an instigating and complex theme as PA and motivation in public service. The most evident findings of our study are concerned with:

(a) A still high level of bureaucracy in the Portuguese PA, which can be reduced with a greater regulatory and procedural simplification and with the digitalisation of services (and many efforts have already been made in this direction, some quite innovative such as SIMPLEX);

(b) A weakness in the motivation of civil servants, generated by several intrinsic and extrinsic factors, such as low salaries, little career progression elasticity, a performance evaluation system that does not reward the efforts of employees, lack of recognition and prestige of civil servants by society, among others;

(c) Politicisation rooted in the appointment of board positions, whether of a partisan nature or a culture of "cronyism", with some undesirable developments (not in line with a meritocracy), for example, leaders who are not qualified for the position, less scrutiny in the fight against corruption, favouritism in SIADAP progression quotas. 
Additionally, worthy of mention was the high evaluation found of the services provided in the Lojas do Cidadão (Citizens' Shops), which in the face of the other variables that had a negative evaluation surprised us positively, corroborating, in some way, the understanding that civil servants are motivated by carrying out a mission for the common good, defended by Crewson (1997). Conversely:

"Although working in public entities has been related to 'a sense of duty and morality', literature reports that motivation and sense of self-worth among public officials have been declining for many years, which in turn can endanger their performance, [and] diminish their willingness to attend to civic affairs" (Santinha et al. 2021, p. 1).

It follows that less motivated public officials will be less committed to their organisations, including in Portugal, even after the changes put into effect after the 1980s (Santinha et al. 2021). The literature (Santinha et al. 2021) suggests that the objective of attaining job stability may perhaps not be a fulfilling career choice. Our research is in line with these findings.

Regarding the public's perception of bureaucracy, Kennedy (2018) notes that the term is usually used in a pejorative sense to signal organisational inefficiency and ineffectiveness, and public support is critical to the proper functioning of public institutions and the State. From this perspective, could the high degree of perception of bureaucracy found in our study be "contaminated" by common sense that bureaucracy is a weed for society?

A timely reflection on the study is that it was answered in the middle of the COVID-19 pandemic after a prolonged period of confinement that required the PA to make great efforts to combat the resulting health and economic crises. In addition to the unconditional commitment of the professionals of the National Health Service, there was a lot of commitment to make online services available for the attendance of citizens and companies, for remote processing of judicial processes and for distance learning at all levels of education. In a scenario of overcoming adversity, it would be expected that civil servants would enjoy greater recognition and prestige among the Portuguese (which our findings did not actually indicate).

Although this study has thrown some insights into the ongoing debate on the Portuguese PA, it has some limitations. One of them (and perhaps the most important) is the high level of educational qualifications found among the respondents, which may have caused some bias in the results. The study was widely disseminated in universities, polytechnics, schools, companies and trade associations, parish councils in all districts of Portugal, in addition to some social media channels. The academic environment, due to its final activity of teaching and research, is supposed to be more inclined to collaborate with research projects and respond to surveys. Moreover (and unfortunately), not all segments of society have access to electronic means to respond to surveys.

Consequently, the sample obtained with the study could be considered representative in quantitative terms if we took into account the population in general, but not in qualitative terms (despite the effort made to contemplate all segments of society, this has not materialised). Another aspect to be raised regarding the sample is that our study intended to compare the differences of opinion between the public sector and other sectors of activity. In this context, the sample, separately, could be considered as not representative of these sectors.

We hope that this study may instigate new investigations and developments. Suggestions for future research include the application of the questionnaire exclusively to public sector workers, to occupants of management positions or to specific sectors of the PA, such as health professionals, in comparative studies or not. We consider that the variables used are of universal character and may be applied in other cultures and contexts.

Additionally, Portugal has an ageing population that may feel estranged from the digital revolution, which has occurred due to COVID-19 (only $1 \%$ of the survey respondents were over 70 years of age). Future studies might intend to study this section of the Portuguese population, which is hard to reach in an online survey. 
Public organisations must always be focused on citizens (alternatively understood as users or customers), on the way they deliver their services and on the results of the application of these services in society (Falcão et al. 2014). Even when knowing that perceptions of Portuguese public service may also vary from region to region, including when the distance covered is a mere $48 \mathrm{~km}$ or just over half an hour by car (Falcão et al. 2014), PA is not an easy task and requires a motivated workforce with a vision for their efforts. Future studies may focus on the topics discussed herein but be analysed by region (e.g., larger urban centres versus inland and less densely populated areas).

Author Contributions: Conceptualization, A.Z.F.C.N., A.M., M.J.S. and M.A.-Y.-O.; methodology, A.Z.F.C.N., A.M., M.J.S. and M.A.-Y.-O.; investigation: A.Z.F.C.N., M.A.-Y.-O.; software: A.Z.F.C.N., A.M., M.A.-Y.-O. and M.J.S.; validation, A.M., M.A.-Y.-O. and M.J.S.; writing-original draft preparation, A.Z.F.C.N., M.A.-Y.-O.; writing-review and editing, A.Z.F.C.N., A.M., M.A.-Y.-O. and M.J.S.; supervision, M.A.-Y.-O. and M.J.S.; funding, M.J.S. All authors have read and agreed to the published version of the manuscript.

Funding: This research received no external funding.

Institutional Review Board Statement: Ethics Committee review was waived because the investigation did not involve clinical trials with patients. The PhD project was registered after approval by the Scientific Council of the University of Aveiro.

Informed Consent Statement: Informed consent was obtained from all subjects involved in the study.

Data Availability Statement: Not applicable.

Acknowledgments: The authors would like to thank the valuable comments received from two anonymous reviewers and an academic editor from the journal. The authors also acknowledge the contribution of the participants who answered the survey.

Conflicts of Interest: The authors declare no conflict of interest.

\section{Appendix A}

Table A1. Survey questions on the Portuguese PA.

\begin{tabular}{|c|c|}
\hline Questions & Typology of Responses \\
\hline $\begin{array}{l}\text { How bureaucratic do you believe the Portuguese } \\
\text { Public Administration to be? }\end{array}$ & $\begin{array}{l}\text { Likert Scale } \\
\text { Not at all bureaucratic } \\
\text { A little bureaucratic } \\
\text { Moderately bureaucratic } \\
\text { Quite bureaucratic } \\
\text { Very bureaucratic }\end{array}$ \\
\hline $\begin{array}{l}\text { What is your opinion on the number of civil } \\
\text { servants in Public Administration Bodies? }\end{array}$ & $\begin{array}{c}\text { Multiple choice } \\
\text { There are few employees } \\
\text { The number of employees is adequate } \\
\text { There are too many employees } \\
\text { It is not well distributed, and there is both a } \\
\text { shortage and excess in different areas } \\
\text { I don't have a fixed opinion }\end{array}$ \\
\hline $\begin{array}{l}\text { On a scale of } 1 \text { (very bad) to } 5 \text { (excellent), how do } \\
\text { you rate the image of the civil servant in } \\
\text { relation to: }\end{array}$ & $\begin{array}{c}\text { Matrix with Likert scale } \\
\text { Efficiency } \\
\text { Qualification } \\
\text { Commitment } \\
\text { Ethics } \\
\text { Motivation }\end{array}$ \\
\hline
\end{tabular}


Table A1. Cont.

\begin{tabular}{|c|c|}
\hline Questions & Typology of Responses \\
\hline $\begin{array}{c}\text { Are you in favour of recognising the work of the } \\
\text { individual in the civil service (monetary prizes } \\
\text { and diplomas of merit, etc.)? }\end{array}$ & $\begin{array}{l}\text { Likert Scale } \\
\text { I do not agree at all } \\
\text { I agree in part } \\
\text { I moderately agree } \\
\text { I agree very much } \\
\text { I strongly agree }\end{array}$ \\
\hline $\begin{array}{l}\text { Do you believe it is possible to innovate in Public } \\
\text { Administration? }\end{array}$ & $\begin{array}{l}\text { Multiple choice } \\
\text { Yes } \\
\text { No } \\
\text { I'm not sure }\end{array}$ \\
\hline $\begin{array}{l}\text { Have you ever been to a Loja do Cidadão? } \\
\text { (Citizens' Shop)? }\end{array}$ & $\begin{array}{l}\text { Multiple choice } \\
\text { Yes } \\
\text { No }\end{array}$ \\
\hline $\begin{array}{l}\text { How do you rate the quality of the service you } \\
\text { sought in the Loja do Cidadão? (Citizens' Shop?) }\end{array}$ & $\begin{array}{l}\text { Likert Scale } \\
\text { Very bad } \\
\text { Bad } \\
\text { Reasonable } \\
\text { Good } \\
\text { Excellent }\end{array}$ \\
\hline $\begin{array}{l}\text { What would you change in the Public } \\
\text { Administration if you could? }\end{array}$ & $\begin{array}{l}\text { Semi-structured and optional question, no } \\
\text { character limit for answer }\end{array}$ \\
\hline
\end{tabular}

\section{References}

Albury, David. 2005. Fostering innovation in public services. Public Money and Management 25: 51-56.

Alonso, Pablo, and Gregory B. Lewis. 2001. Public service motivation and job performance: Evidence from the federal sector. The American Review of Public Administration 31: 363-80. [CrossRef]

Alves, Patricia, Vasco Santos, Isabel Reis, Filipa Martinho, Domingos Martinho, Marta Correia Sampaio, Maria José Sousa, and Manuel Au-Yong-Oliveira. 2020. Strategic Talent management: The impact of employer branding on the affective commitment of employees. Sustainability 12: 9993. [CrossRef]

Agency for Administrative Modernisation (AMA). 2021. Available online: https://www.ama.gov.pt/web/agencia-para-amodernizacao-administrativa/mais-ap (accessed on 6 June 2021).

Araújo, Joaquim F. F. E. 2005. A Reforma Administrativa em Portugal: Em Busca de um Novo Paradigma. Braga: Universidade do Minho, Núcleo de Estudos em Administração e Políticas Públicas.

Bekkers, Victor J. J. M., Lars G. Tummers, and William H. Voorgerb. 2013. From Public Innovation to Social Innovation in the Public Sector: A Literature Review of Relevant Drivers and Barriers. Rotterdam: Erasmus University Rotterdam.

Bellé, Nicola, and Edoardo Ongaro. 2014. NPM, administrative reforms and public service motivation: Improving the dialogue between research agendas. International Review of Administrative Sciences 80: 382-400. [CrossRef]

Bilhim, João, Ricardo Ramos, and Luís M. Pereira. 2015. Paradigmas administrativos, ética e intervenção do Estado na economia: O caso de Portugal. Revista Digital de Derecho Administrativo 14: 91-125. [CrossRef]

Borins, Sandford F. 2002. Leadership and innovation in the public sector. Leadership \& Organization Development Journal 23: 467-76.

Brewer, Gene A., and Sally C. Selden. 1998. Whistle blowers in the federal civil service: New evidence of the public service ethic. Journal of Public Administration Research and Theory 8: 413-39. [CrossRef]

Bryman, Alan, and Emma Bell. 2015. Business Research Methods, 4th ed. New York: Oxford University Press.

Buarque de Holanda, Sérgio. 1987. Raízes do Brasil, 19th ed. Rio de Janeiro: José Olympio.

Cardoso, Sónia, Teresa Carvalho, and Pedro Videira. 2019. Is It Still Worth Working In Academia? The Views from Portuguese Academics. Higher Education Policy 32: 663-79. [CrossRef]

Carvalho, Elisabete R. 2008. Agendas e Reforma Administrativa em Portugal. Ph.D. thesis, Institute of Social and Political Sciences, Technical University of Lisbon, Lisbon, Portugal.

Castro, Marilú P., and Tomas A. Guimarães. 2019. Dimensões da inovação em organizações da justiça: Proposição de um modelo teórico-metodológico. Cadernos EBAPE.BR 17: 173-84. [CrossRef]

Economic and Social Council of Portugal (CES). 2019. Parecer Sobre o Programa Nacional de Reformas $2016-2023$ (April 2019 Update). Available online: https:/ / www.ces.pt/storage/app/uploads/public/5cb/f26/14c/5cbf2614c3601933843274.pdf (accessed on 6 June 2019).

Chiavenato, Idalberto. 2009. Administração Geral e Pública. Teoria e mais de 500 Questões com Gabarito, 2nd ed. Rio de Janeiro: Elsevier. 
Corte-Real, Isabel. 2008. Public management reform in Portugal: Successes and failures. International Journal of Public Sector Management 21: 205. [CrossRef]

Crewson, Philip E. 1997. Public service motivation: Building empirical evidence of incidence and effect. Journal of Public Administration Research and Theory 7: 499-518. [CrossRef]

Diário da República Eletrónico. 2021. Resolução do Conselho de Ministros N 55/2020. Available online: https://dre.pt/home/-/dre/ 139209032/details/maximized (accessed on 10 June 2021).

Dias, Fernanda F. 2016. O Mercado único digital europeu. European Review 1: 17-41.

Directorate-General for Public Administration and Employment (DGAEP). 2021. Portuguese Central Public Administration Overview of Employment. Lisbon: Directorate-General for Administration and Public Employment.

EcoSapo. 2021. Antes Eram Jobs for the Boys. Agora é Money for the Boys. Available online: https:/ /eco.sapo.pt/opiniao/opiniao-depedro-sousa-carvalho-antes-eram-jobs-for-the-boys-agora-e-money-for-the-boys / (accessed on 10 June 2021).

European Commission. 2020a. The European Economy Since the Start of the Millennium. A Statistical Portrait-Data 2000-2019. Available online: https:/ / ec.europa.eu/eurostat/cache/digpub/european_economy/bloc-4d.html?lang=en (accessed on 9 June 2021).

European Commission. 2020b. Índice de Digitalidade da Economia e da Sociedade (IDES) de 2020: Portugal. Available online: https:/ / www.adcoesao.pt/sites/default/files/files/noticias/desi2020_portugal.pdf (accessed on 7 October 2020).

Executive Digest Sapo. 2021. SNS Perdeu 800 Médicos Desde o Início da Pandemia. Available online: https://executivedigest.sapo.pt/ sns-perdeu-800-medicos-desde-o-inicio-da-pandemia/17/02/2021 (accessed on 9 June 2021).

Expresso. 2021. Quantas Horas de Espera nos Serviços Públicos vai a Bazuca Cortar. Available online: https://expresso.pt/economia / 2021-06-08-Quantas-horas-de-espera-nos-servicos-publicos-vai-a-bazuca-cortar--939dafb2 (accessed on 10 June 2021).

Falcão, Rita L., Maria H. Monteiro, and Célio G. Marques. 2014. O nível de qualidade oferecido pelos serviços eletrónicos na Administração Pública Local em Portugal. Um caso de estudo na NUTS II-Lisboa. Paper presented at 14th Conferência da Associação Portuguesa de Sistemas de Informação (CAPSI 2014), Évora, Portugal, October 3-4.

Ferraz, David. 2020. Administracão (a)política? O retrato e os fatores de seleção do dirigente público. Revista de Administração Pública 54: 1166-87.

Fraga, Ana R. H. 2014. O Impacto das Reformas e Austeridade na Administração Pública Sobre os Funcionários Públicos: Um Estudo de Caso. Master's dissertation, University Institute of Lisbon, Lisbon, Portugal.

Gieske, Hanneke, Arwin Van Buuren, and Victor Bekkers. 2016. Conceptualizing public innovative capacity: A framework for assessment. The Innovation Journal 21: 1.

Gil, Antonio C. G. 2017. Como Elaborar Projetos de Pesquisa, 6th ed. São Paulo: Atlas.

Gouveia, Luís B. 2009. Modelos de Governação na Sociedade da Informação e do Conhecimento. Lisboa: Associação para a Promoção e o Desenvolvimento da Sociedade da Informação.

Gruening, Gernod. 2001. Origin and theoretical basis of New Public Management. International Public Management Journal 4: 1-25. [CrossRef]

Herzberg, Frederick. 1987. One more time: How do you motivate employees? Harvard Business Review 65: 109-20.

Hofstede, Geert. 2001. Culture's Consequences: Comparing Values, Behaviours, Institutions, and Organizations Across Nations, 2nd ed. Thousand Oaks: Sage Publications.

Hood, Christopher. 1991. A Public management for all seasons? Public Administration 69: 3-19. [CrossRef]

Hood, Christopher. 1994. The "New Public Management" in the 1980s: Variations on a theme. Accounting, Organizations and Society 20: 93-109. [CrossRef]

House, Robert J., Paul J. Hanges, Mansour Javidan, Peter W. Dorfman, and Vipin Gupta, eds. 2004. Culture, Leadership and OrganizationsThe GLOBE Study of 62 Societies. Thousand Oaks: Sage Publications.

Houston, David J. 2006. Walking the walk' of public service motivation: Public employees and charitable gifts of time, blood, and money. Journal of Public Administration Research and Theory 16: 67-86. [CrossRef]

National Institute of Statistics (INE). 2021. Managers in Sector of Public Administration. Available online: https://www.ine.pt/ xportal/xmain?xpid=INE\&xpgid=ine_indicadores\&contecto=pi\&indOcorrCod=0007318\&selTab=tab0\&xlang=en $($ accessed on 10 June 2021).

Jamil, Ishtiaq. 1998. La cultura administrativa: Una forma de comprender la administración pública en distintas culturas. Gestión y Política Pública 7: 61-82.

Kennedy, Brandy. 2018. Bureaucracy and Public Opinion. In Global Encyclopedia of Public Administration, Public Policy, and Governance. Edited by Ali Farazmand. Cham: Springer.

Kim, Sangmook. 2009. Revising Perry's measurement scale of public service motivation. The American Review of Public Administration 39: 149-63. [CrossRef]

King, Daniel, and Scott Lawley. 2016. Organizational Behaviour, 2nd ed. Oxford: Oxford University Press.

Experimentation Laboratory for Innovation in the Public Sector (LabX). 2021. Public Services Citizen Centric. Available online: https:/ /labx.gov.pt/?lang=en (accessed on 7 June 2021).

Lane, Jan-Erik. 1995. Public Sector: Concepts, Models and Approaches. London: Sage Publications.

Lopes, Cátia I. C. 2012. Os Fatores Motivacionais dos Trabalhadores da Administração Local. Master's dissertation, School of Business Sciences of the Polytechnic Institute of Setúbal, Setúbal, Portugal. 
Madureira, César G. 2015. A reforma da Administração Pública Central no Portugal democrático: Do período pós-revolucionário à intervenção da troika. Revista de Administração Pública. Revista de Administração Pública 49: 547-62. [CrossRef]

Madureira, César G., and David Ferraz. 2010. The need of a XXI century governance paradigm for public administration-The specific case of Portugal. Public Policy and Administration-Viesoji Politika ir Administravimas 31: 35-48.

Madureira, César G., and Miguel Rodrigues. 2015. Fatores de motivação dos trabalhadores na Administração Pública Central em Portugal. Revista de Administração e Emprego Público 2: 83-110.

Madureira, César G., Maria Asensio, and Miguel Rodrigues. 2013. Análise da Evolução das Estruturas da Administração Pública Central Portuguesa Decorrente do PRACE e do PREMAC. Lisboa: DGAEP.

Madureira, César G., Belén Rando, and David Ferraz. 2021. The Public Administration Performance Appraisal Integrated System (SIADAP) and the Portuguese Civil Servants Perceptions. International Journal of Public Administration 44: 300-10. [CrossRef]

Magone, José M. 2011. The difficult transformation of State and Public Administration in Portugal. Europeanization and the persistence of neo-patrimonialism. Public Administration 89: 756-82. [CrossRef]

Marques, Maria C. C. 2016. A governação pública na era digital: O caso português. Revista Iberoamericana de Contabilidad de Gestion 14: $1-13$.

Maslow, Abraham. 1954. Motivation and Personality, 2nd ed. New York: Harper \& Row.

Mayo, Elton. 1959. Problemas Humanos de una Civilización Industrial. Buenos Aires: Galares-Nueva Visión.

McClelland, David C. 1972. A Sociedade Competitiva: Realização e Progresso Social. Rio de Janeiro: Expressão e Cultura.

McGregor, Douglas. M. 1960. The Human Side of Enterprise. New York: McGraw-Hill.

Melo, Sara, Lode De Waele, and Tobias Polzer. 2020. The role of Post-New Public Management in shaping innovation: The case of a public hospital. International Review of Administrative Sciences. Available online: https://journals.sagepub.com/toc/ras/0/0 (accessed on 7 June 2021). [CrossRef]

Mintzberg, Henry. 1996. Managing government, governing management. Harvard Business Review 96306: 75-83.

Nishimura, Adriana Z. F. C., and Manuel Au-Yong-Oliveira. 2021. Perspetivas sobre o e-Government em Portugal: Um estudo qualitativo. Revista Ibérica de Sistemas e Tecnologias de Informação 42: 276-94.

Organisation for Economic Co-operation and Development (OECD). 1995. Managing Administrative Reform: A Case Study of Portugal (1976-1994). Public Management Occasional Papers. Paris: OECD.

Ongaro, Edoardo. 2015. Five challenges for public administrations in Europe. Administration 63: 67-77. [CrossRef]

Pandey, Sanjay K., Bradley E. Wright, and Donald P. Moynihan. 2008. Public service motivation and interorganizational citizenship behavior: Testing a preliminary model. International Public Management Journal 11: 89-108. [CrossRef]

Pedro, Marcelina M. 2015. Fatores que Contribuem para a Motivação dos Trabalhadores da Administração Local: Estudo de Caso Numa Autarquia Local. Master's dissertation, School of Business Sciences of the Polytechnic Institute of Setúbal, Setúbal, Portugal.

Pérez-Ramos, Juan. 1990. Motivação no trabalho: Abordagens teóricas. Psicologia USP 1: 127-40.

Perry, James L. 1996. Measuring public service motivation: An assessment of construct reliability and validity. Journal of Public Administration Research and Theory 6: 5-22. [CrossRef]

Polónia, Daniel F., Gonçalo P. Dias, and José A. Rafael. 2014. Strategic planning in the implementation of an e-government regional system: The Porto Santo case. Paper presented at 9th Iberian Conference on Information Systems and Technologies (CISTI 2014), Barcelona, Spain, June 18-21; pp. 353-58.

Portuguese Republic. 2018. Programa Nacional de Reformas (PNR). Updated in April 2018. Available online: https://www.portugal. gov.pt/upload/ficheiros/i007132.pdf (accessed on 10 January 2019).

Rato, Maria H. 2015. A administração pública e a política de austeridade em Portugal. Revista de Administração e Emprego Público. Revista de Administração e Emprego Público 1: 115-41.

Ritz, Adrian. 2011. Attraction to public policy-making: A qualitative inquiry into improvements in PSM measurement. Public Administration 89: 1128-47. [CrossRef]

Rocha, José A. O., and Joaquim F. Araújo. 2006. Administrative Reform in Portugal: Prospects and Dilemmas. Milan: European Group of Public Administration (EGPA).

Rodrigues, Marcus V. C. 1994. Qualidade de Vida no Trabalho: Evolução e Análise no Nível Gerencial. Petrópolis: Vozes.

Rodríguez Bolívar, Manuel P., María del C. C. Pérez, and Antonio M. López-Hernández. 2015. Online budget transparency in OECD member countries and administrative culture. Administration $\mathcal{E}$ Society 47: 943-82.

Rosa, Eugénio. 2020. A Administração Pública Portuguesa presente e futuro: Contributos para a reflexão sobre a situação atual, sobre a gestão pública e sobre os caminhos futuros. Revista de Administração e Emprego Público 6: 109-35.

RTP. 2021. IPO Lisboa Perde 50 Técnicos de Saúde em Pouco Mais de um Mês. Available online: https:/ /www.rtp.pt/noticias/pais/ ipo-lisboa-perde-50-tecnicos-de-saude-em-pouco-mais-de-um-mes_n1325859 (accessed on 7 June 2021).

Santinha, Gonçalo, Teresa Carvalho, Teresa Forte, Alexandre Fernandes, and Jéssica Tavares. 2021. Profiling public sector choice: Perceptions and motivational determinants at the pre-entry level. Sustainability 13: 1272. [CrossRef]

Schein, Edgar H. 1992. Organizational Culture and Leadership, 2nd ed. San Francisco: Jossey-Bass.

Transparency International Portugal. 2021. Corruption Perceptions Index 2019 and Global Corruption Barometer 2021. Available online: https: / / transparencia.pt/ (accessed on 16 June 2021).

Trigo, Maria. R. 2020. O funcionário público e sua imagem social. Entremeios: Journal of Discourse Studies 22: 187-203. [CrossRef]

Trochim, William M. K. 2000. The Research Method Knowledge Base, 2nd ed. Cincinnati: Atomic Dog Publishing. 
Violin, Tarso C. 2007. Da Administração Pública patrimonialista à Administração Pública gerencial e a burocracia. AEC Revista de Direito Administrativo \& Constitucional 30: 225-47.

Vroom, Victor H. 1964. Work and Motivation. New York: John Wiley \& Sons.

Weber, Max. 2000. Economia e Sociedade. Fundamentos da Sociologia Compreensiva, 4th ed. Brasília: Editora da UnB.

Wright, Vincent. 1997. Redefiniendo el Estado: Las implicaciones para la administración pública. Gestion y Analisis de Políticas Públicas 7: 27-44. [CrossRef]

Wright, Bradley E., and Adam M. Grant. 2010. Unanswered questions about public service motivation: Designing research to address key issues of emergence and effects. Public Administration Review 70: 691-700. [CrossRef] 